\title{
EL PESO DE LA SALVACIÓN: \\ MISIONEROS Y PROCURADORES JESUITAS DE LAS ISLAS MARIANAS Y LA NUEVA ESPAÑA \\ $(1660-1672)^{*}$
}

\author{
Alexandre Coello de la Rosa \\ Universitat Pompen Fabra/CSIC-ICREA Academia
}

SAN VITORES EN LA NUEVA ESPAÑA (1660-1662)

$\mathrm{F}$ n un contexto de expansión político-religiosa, la misión sionera diseñado por la Compañía de Jesús y la Santa Sede en el marco de la Reforma católica. Desde sus inicios, la conquista y colonización del archipiélago no fue una empresa muy rentable para la corona española. La isla de San Juan, luego conocida como Guam (o Guåhån), es la principal y más meridional de las 15 islas e islotes que componen las Marianas, un archipiélago de origen volcánico y coralino que se extienden de norte a sur formando un amplio arco de más de 800 kilómetros en el Pacífico occidental, entre el trópico de Cáncer y el ecuador. La falta de

Fecha de recepción: 25 de mayo de 2020

Fecha de aceptación: 24 de septiembre de 2020

* Este artículo forma parte del proyecto Mediaciones Culturales en los Imperios Ibéricos: diplomacia intercultural y misiones en Asia y el Pacífico (siglos XVI-XVIII). IP: Joan-Pau Rubiés (MINECO/AEI FFI2016-79496-P). Agradezco los atinados comentarios de los dictaminadores. 
metales preciosos, en contraste con la opulencia del continente americano, parecía justificar su abandono. La topografía de la isla estaba atravesada por pequeños barrancos y cañadas, $\mathrm{y}$ además, los galeones de la ruta de Acapulco tenían serias dificultades para acceder a sus costas. ${ }^{1}$ A pesar de estos inconvenientes, el padre San Vitores deseaba plantar allí la semilla del evangelio y convertirse en mártir de la cristiandad.

El 15 de mayo de 1660, el padre burgalés se embarcó desde Cádiz en la flota que se dirigía a la Nueva España, llegando a Veracruz el 28 de julio del mismo año. ${ }^{2}$ Según la Historia de las islas Marianas (Manila, 1701) del padre Morales, "la travesía fue corta y feliz". ${ }^{3}$ Posteriormente se trasladó a la capital mexicana, donde el 2 de diciembre obtuvo la profesión solemne de cuatro votos antes de pasar a las Filipinas. ${ }^{4}$ En los dos años que estuvo en México fue director de ejercicios espirituales, ocupándose de reformar las costumbres de una ciudad "sumida en el lujo y dispersión”. Al escuchar sus sermones, el virrey don Juan Francisco de Leiva y de la Cerda (1660-1664), Conde de Baños, trató de persuadirle para que se ocupara de tantos "pecadores e infieles", en lugar de embarcarse a las Islas del Poniente. ${ }^{5}$

Sin embargo, la tarea más importante de San Vitores, especialmente para el futuro de las Islas Marianas, fue el restablecimiento de la ilustre congregación de San Francisco Javier, cuya popularidad en la ciudad de México era enorme. Dicha congregación o hermandad fue fundada originalmente el 12 de diciembre de 1657 por el bachiller Cristóbal Javier Vidal Figueroa en la parroquia de la Santa Veracruz, con el fin de conmemorar las

1 ARSI, Philipp. 14, ff. 64r.-68r.; ReIchert, "La transcripción del manuscrito de fray Ignacio Muñoz", p. 162.

2 Zambrano, Diccionario bio-bibliográfico, vol. xiII, p. 777.

3 Morales y Le Gobien, Historia de las islas Marianas.

${ }^{4}$ García, Vida y martyrio, p. 107.

${ }^{5}$ Morales y Le Gobien, Historia de las islas Marianas, f. 9. 
fiestas en honor del santo jesuita. ${ }^{6}$ Los congregantes, 33 hombres seglares, 33 mujeres y 33 sacerdotes, entre los que se encontraba el mismísimo papa Alejandro VII (1655-1667), se ocupaban de diversos ministerios, como los fervorosos actos de contrición por las calles públicas, el socorro a doncellas desvalidas, la explicación de la doctrina cristiana. La congregación contaba, pues, con sólidos apoyos, no solo del papa, sino también del entonces virrey don Francisco Fernández de la Cueva, Duque de Albuquerque (1653-1660), para trabajar por la salvación de las almas. ${ }^{7}$ Asimismo, los congregantes "acudían a las cárceles y hospitales a servir, consolar y socorrer a los enfermos y encarcelados", dando limosna a los pobres vergonzantes y ejercitando obras de misericordia corporal y espiritual. ${ }^{8}$ Su función era apoyar, y en muchas ocasiones sustituir, a los religiosos de la Compañía de Jesús, quienes tenían asignada la asistencia espiritual a los condenados a muerte.

El 12 de abril de 1671, el padre Joseph Vidal de Figueroa (1630-1703), rector del Colegio de San Ildefonso, ${ }^{9}$ solicitó al padre provincial fomentar "el ministerio de los justiciados". ${ }^{10}$ Desde 1663, el padre Vidal había compatibilizado sus cátedras

\footnotetext{
${ }^{6}$ Peralta de Calderón, El Apóstol de las Indias, f. 268; Zambrano, Diccionario bio-bibliográfico, vol. xIII, pp. 777, 780-781.

7 Peralta de Calderón, El Apóstol de las Indias, f. 284; Alegre, Historia de la Compañia de Jesús, vol. III (1640-1675), p. 248.

8 García, Vida y martyrio, p. 105; Alegre, Historia de la Compañia de Jesús, vol. III, p. 247.

9 El padre Vidal era lector de la cátedra de Teología Moral y Escritura en el Colegio Máximo de San Ildefonso de la Nueva España. El padre San Vitores lo apreciaba mucho. En una carta dirigida al general Giovanni Paolo Oliva (1664-1681) escribió que [Vidal de Figueroa] era "de los talentos de espíritu, letras y prudencia” de la provincia mexicana. ARSI, México 17, f. 345r. Se ocupó de visitar las cárceles y de fomentar las misiones circulares, según lo practicaba San Pablo. En 1674, a petición del obispo Diego Osorio de Escobar (1655-1676), el padre Vidal se ocupó de la misión de Puebla. Alegre, Historia de la Compañía de Jesús, vol. III, pp. 272-273, 320; vol. Iv (1676-1766), pp. 5-6.

${ }^{10}$ ARSI, México 17, f. 315r.
} 
de Escritura y Teología Moral en el Colegio Máximo con su dedicación a los pobres, visitando las cárceles y acompañando a los ajusticiados. ${ }^{11}$ Sin embargo, parece que sus deseos no se cumplieron y en 1673 denunciaba que sus cofrades no atendían debidamente este ministerio. Así,

En otra ocasión se ha puesto orden muy apretado que [los padres jesuitas] vayan de la Profesa, y como los padres que suelen vivir allí no gustan mucho de este ministerio, iban a la cárcel y estando un rato se despedían, diciendo al capellán qué necesidad hay de nosotros, estando aquí Vuestra Merced, y dejaban solo al justiciado, de lo cual dio la queja el señor Marqués [de Mancera, virrey] y los alcaldes que han hecho todo empeño porque asista la Compañía a este ministerio. ${ }^{12}$

La miseria moral y material que padecían los plebeyos de la capital novohispana fue una de las principales preocupaciones del gobierno del virrey don Antonio Sebastián de Toledo, Molina y Salazar, Marqués de Mancera (1664-1673). Como apuntó Douglas Cope, la posibilidad de una potencial revuelta surgida del "ámbito plebeyo" puso en aprietos al gobierno colonial. ${ }^{13}$ Entre 1661 y 1662, las actividades apostólicas del padre San Vitores se concentraron en fomentar el acto de contrición, que como señala Paolo Broggio, consistía en

[...] una processione, da svolgersi dopo il tramonto del sole, che partendo dalla chiesa principale percorreva tutti i punti salienti della

11 Alegre, Historia de la Compañia de Jesús, vol. III, pp. 272-273.

12 "Carta del padre Joseph Vidal al padre provincial Manuel de Arteaga sobre el traslado del suscrito a las misiones de Marianas. Cita los puntos de vista del padre Andrés de Cobián sobre la asistencia que deben dar los religiosos de la orden a los condenados a muerte" (Real del Monte, Hidalgo, 1673). AGN, Jesuitas I, c. 18, leg. 1-11, exp. 141, ff. 125-126.

13 Douglas Cope, The Limits of Racial Domination, pp. 25-26. 
città. Era guidata da una persona armata di un campanello, con il quale avvisava la gente del suo passaggio, seguito da un'immagine del Cristo crocifisso illuminata da due persone con delle lanterne; ancora dietro camminavano i ministri evangelici, e in ultimo il popolo silente. ${ }^{14}$

Una solemne procesión de penitencia pública que fue contemplada por las autoridades como un vademecum necesario en tiempos de crisis. ${ }^{15}$ En una ocasión, la procesión salió al anochecer. Estaba encabezada por un crucifijo y la seguían varios fieles con velas encendidas. Al poco tiempo se acercó un hombre pidiendo confesarse de un pecado terrible que había cometido, a saber, la venta de su alma al diablo a cambio de conseguir los favores de una mujer. Para ello firmó una escritura con su propia sangre, y luego, la escondió en lugar seguro. Una vez conseguido su propósito carnal, la escritura desapareció, y al verse condenado, se arrepintió de sus culpas, "e hizo cuanto el confesor le mandó para alcanzar el perdón de todas ellas". ${ }^{16}$

Asimismo, San Vitores publicó un libro devocionario de notable extensión, El Apóstol de las Indias y nuevas gentes San Francisco Javier de la Compañia de Jesús. Epítome de sus apostólicos hechos, virtudes, enseñanzas y prodigios antiguos y nuevos (México, 1661), utilizando el pseudónimo de licenciado Matías Peralta de Calderón. ${ }^{17}$ No se trataba de una historia crítica sino de una colección de milagros y gracias singulares que habían ocurrido por intercesión del padre jesuita en todo el

14 Broggio, "La questione dell’identità missionaria”, p. 250.

15 Burrieza, “Las Glorias del segundo siglo (1622-1700)”, pp. 164-168.

16 "Breve relación de algunos casos memorables que se ha dignado Nuestro Señor obrar por medio de la doctrina y actos de contricción (1663)”. ARSI, México 17, f. $290 \mathrm{v}$.

17 Zambrano, Diccionario bio-bibliográfico, vol. xII, pp. 90-91; vol. XIII, p. 777. Véase también Payo Hernanz, "Aportaciones para el estudio de la iconografía del martirio", pp. 67-68. 
orbe católico. Un abanico de virtudes que, además de demostrar el carácter universal de la monarquía hispánica, establecía claras conexiones entre San Pablo y la vocación misionera de la Compañía de Jesús. ${ }^{18}$

En 1660, los miembros de la Congregación, ${ }^{19}$ dirigidos por el bachiller Cristóbal Vidal, hermano del jesuita Joseph Vidal de Figueroa, habían adquirido una nueva reliquia "de las entrañas del santo, de cuyo cuerpo tomó el padre Marcelo Mastrilli, quando por los años 1636 de camino para Japón visitó a S.F.X. [San Francisco Xavier] en su sepulcro de Goa”. ${ }^{20}$ Ni qué decir tiene que las reliquias, por su carácter milagroso, eran veneradas por los fieles, especialmente el 17 de agosto, día de la celebración del traslado del cuerpo del santo desde Malaca a Goa, lo que sin duda permitía a los poseedores de dichos objetos atraer limosnas. ${ }^{21}$ Así, al año siguiente, los congregantes proporcionaron a San Vitores un apoyo financiero para la misión que ascendió a más de 3000 pesos en ornamentos y alhajas "y mucha más gruesa cantidad en reales". ${ }^{22}$

SAN VITORES EN FILIPINAS (1662-1667)

Con el propósito de apacentar aquellas ovejas, el padre San Vitores se embarcó con 14 jesuitas el 5 de abril de 1662 en Acapulco

18 Baró, "Redescubriendo a Diego Luis de San Vitores", pp. 27-28. Véase también Zambrano, Diccionario bio-bibliográfico, vol. xIII, pp. 789-790.

19 El ARSI, en Roma, conserva el Memorial que el padre San Vitores dirigió a los caballeros de la Congregación de Francisco Javier de México, describiendo las islas, así como las relaciones de los primeros viajes de los adelantados Álvaro de Mendaña (1595) y Pedro Fernández de Quirós (1610). Finalmente, el 29 de mayo de 1665, San Vitores escribió un Memorial acerca de los motivos para no dilatar más la reducción y doctrina de las Islas de los Ladrones y los medios para llevar a cabo la misión. ARSI, Gesuitico, 849.

20 Peralta de Calderón, El Apóstol de las Indias, f. 269.

21 Alegre, Historia de la Compañia de Jesús, vol. III, p. 248.

22 Alegre, Historia de la Compañia de Jesús, vol. III, p. 258. 
en el patache San Damián con dirección a Manila. A los tres meses llegaba a la isla de Guam, comprobando que, efectivamente, las poblaciones de aquel anecúmene carecían de atención religiosa. ${ }^{23}$ Fue en este breve encuentro con "aquellos pobres desnudos" de las islas cuando San Vitores se interesó vivamente por su conversión. ${ }^{24} \mathrm{El} 10$ de julio arribó al puerto de Lampón [Lampong], en Manila, encontrándose con una población bajo los efectos de revueltas interiores y amenazas exteriores. ${ }^{25} \mathrm{El} 17$ de mayo, el gobernador Manrique de Lara había convocado una junta de guerra en Manila para tomar una decisión trascendental: retirar las guarniciones en Molucas, así como a los dos religiosos jesuitas que se hallaban destinados en la misión de Ternate. ${ }^{26} \mathrm{El}$ motivo no era otro que reforzar las defensas frente a la inminente invasión de Zheng Chenggong (1624-1662), más conocido en las fuentes españolas como Cogseng, Pumpuan o Koxinga, que contaba con un poderoso ejército en la zona continental de Fujian, en la costa sureste de China, con el que pugnaba contra la agonizante dinastía Ming (1368-1644). ${ }^{27}$ El 18 de mayo de 1662, el dominico Vittorio Ricci Florentin (1621-1685), ataviado con las ropas de un mandarín, llegó a Manila como embajador de Koxinga. Portaba un mensaje del líder chino en el que conminaba a las autoridades españolas a rendirle vasallaje. ${ }^{28}$ En 1642 el clan talasocrático de Pumpuan había conquistado la isla Hermosa o Formosa (actual Taiwan), amenazando con invadir las Filipinas. ${ }^{29}$

${ }^{23}$ De la Costa, The Jesuits in the Philippines, p. 455.

${ }^{24}$ García, Vida y martyrio, p. 113.

${ }^{25}$ García, Vida y martyrio, p. 113.

${ }^{26}$ Combés, Historia de Mindanao, Joló, lib. VIII, cap. XIII, pp. 610-613.

27 ARSI, Philipp. 04, f. 45r.

28 Busquets, "Koxinga, los españoles de Manila”, pp. 22-31.

29 Prieto Lucena, Filipinas durante el gobierno de Manrique de Lara, pp. 116-128; Díaz-Trechuelo, Filipinas. La gran desconocida, pp. 148-152. 
Las órdenes religiosas ocupaban espacios de privilegio en las estructuras de poder de las Filipinas, convirtiéndose en puntas de lanza de un orden católico -el "pueblo cristiano", o gens totius orbis, que diría Tertuliano- orientado a engrandecer la monarquía compuesta de los Habsburgo en los enclaves oceánicos del Extremo Oriente. Sin embargo, el 8 de noviembre de 1662, el gobernador Fernando de Bobadilla recibió instrucciones de desmantelar el presidio de Zamboanga, desamparando a los lutaos que vivían allí. Ante las protestas de los cristianos filipinos de la zona, la orden no se ejecutó sino hasta enero de 1663, cuando los gobernadores de los presidios de Zamboanga, Ternate, Calamianes e Iligan, así como los religiosos, abandonaron definitivamente sus posiciones. ${ }^{30}$

En un contexto de inestabilidad y crisis, en 1663 el padre provincial Ignacio Zapata (1595-1666) envió al padre San Vitores a los montes de Santa Inés y Morataya de la residencia de Antipolo, en la isla de Luzón. ${ }^{31}$ La misión dio comienzo el 31 de mayo, día de la Visitación de la Virgen María. Poco después el provincial pidió al padre San Vitores que se ocupara de las doctrinas que los jesuitas administraban en Taytay y Cainta, a seis o siete leguas de Manila, donde aprendió el tagalo con extraordinaria rapidez de la mano del hermano donado Marcos de la Cruz, de nación tagala. ${ }^{32}$

Desde allí San Vitores escribió dos cartas que proporcionaban una alternativa a las misiones que la Compañía había abandonado en el sur de Filipinas. En la primera carta, dirigida al padre Juan Pablo Oliva, prepósito general de la Compañía

30 Majul, Muslims in the Philippines, pp. 113, 181.

31 ARSI, Philipp. 4, f. 47v.; OÑA, Labor Evangélica. Segunda Parte, f. 1474r. El hagiógrafo F. García proporciona otra fecha: 1665. GARcía, Vida y martyrio, p. 130.

32 García, Vida y martyrio, pp. 116-117; Morales y Le GobIen, Historia de las Islas Marianas, f. 11; OÑA, Labor Evangélica. Segunda Parte, ff. 14791483 r. 
(1664-1681), con fecha en Taytay, 22 de julio de 1663, criticaba abiertamente el abandono del presidio de Zamboanga por considerar que se exponía a los cristianos a la presión de los “moros” y al peligro de la apostasía. ${ }^{33}$ En este punto, San Vitores se alineaba con sus cofrades jesuitas, y en particular con el padre Francisco Combés, SJ, cuya Historia de Mindanao, Joló (Madrid, 1667) pretendía convencer a las autoridades metropolitanas de la necesidad de mantenerlo. ${ }^{34}$

Para compensar esta pérdida, San Vitores abogaba por la fundación de una viceprovincia en las Marianas, dado que sus habitantes -“gente apacible y dócil”- no habían visto nunca a ningún clérigo. ${ }^{35}$ En la segunda, dirigida al rey, con fecha en Taytay, 18 de julio, además de la docilidad y buena predisposición de los nativos marianos, esgrimía otro argumento de peso: "la pobreza de las Marianas las convertía en el escenario perfecto en el que establecer una doctrina, pues permitiría a la monarquía española defenderse de las acusaciones de los protestantes”. ${ }^{36} \mathrm{La}$ corona española, acusada de querer enriquecerse y explotar el Nuevo Mundo y a sus habitantes, podría finalmente deshacerse de las múltiples acusaciones y calumnias de sus detractores con el establecimiento de una doctrina en las Islas Marianas, donde no había oro ni otros intereses económicos.

Del mismo modo, el conflicto sobre los ritos chinos, discutidos por los franciscanos y dominicos desde su llegada a China en 1631 y condenados por la Congregación de Propaganda Fide en 1645, cuestionaba la legitimidad del método de

33 El primero que definió a los pueblos malayos de las tierras bajas o litoral de las islas Filipinas como "moros" fue Miguel López de Legazpi (1503-1572), diferenciándolos de los pueblos del interior, donde predominaban los "gentiles". Wenceslao E. Retana, "Notas" a la edición de Antonio de Morga, Sucesos de las Islas Filipinas, p. 40.

${ }^{34}$ Rodríguez-Rodríguez, "Francisco de Combés's History of Mindanao and Joló (1667)", pp. 141-156.

35 ARSI, Philipp. 14, f. 57r.-59v.

36 AHN, Diversos-Colecciones, leg. 27, nº 35, ff. 1r.-2v. 
adaptación cultural practicado por los jesuitas en el Oriente. ${ }^{37}$ No hay que olvidar la difusión que tuvieron las tres cartas -las "Inocencianas" de 1645, 1647 y 1649- que el obispo de Puebla de los Ángeles, Juan de Palafox y Mendoza (1640-1653), dirigió al papa Inocencio X (1644-1655). Dichas cartas suscitaron gran inquietud en amplios sectores eclesiásticos, especialmente dominicos y franciscanos, contribuyendo a "la construcción de una temprana esfera pública global". ${ }^{38}$ Sus críticas al relajamiento moral de los jesuitas, ejemplificadas en la doctrina del probabilismo y el laxismo, dieron lugar a una serie de enconados debates y enfrentamientos que llegaron a pedir la supresión de la Compañía de Jesús. ${ }^{39}$

En 1654 se publicó el Teatro jesuítico, apologético discurso, con saludables y seguras doctrinas, necesarias a los principes y señores de la tierra (Coimbra, 1654), un punto de inflexión en lo que Gil San Juan denominó "el salto a la guerra sucia, llena de descalificaciones, mendacidades, sátiras y panfletos corrosivos" contra la Compañía de Jesús. ${ }^{40}$ Gobernadores, arzobispos, oidores y prebendados del cabildo de Manila se vieron envueltos en una "literatura de trinchera" orientada a deshonrar, criticar, injuriar o destruir la reputación y honorabilidad de sus enemigos políticos. ${ }^{41} \mathrm{El}$ tema resulta de gran interés porque nos introduce en las formas de transmisión de una literatura no autorizada pero de gran influencia en el Antiguo Régimen: pasquines, libelos y papeles satíricos que con "indecorosa indignidad e impostura" cargaban sus tintas contra los jesuitas, especialmente tras la caída

37 Cervera y Martínez Esquivel, "Puebla de los Ángeles, entre China y Europa”, pp. 248-249; 255.

38 Cervera y Martínez Esquivel, "Puebla de los Ángeles, entre China y Europa”, p. 246.

39 Burrieza, "Los misioneros en la Monarquía”, pp. 189-193; Álvarez de Toledo, Juan de Palafox, pp. 101-111; Burrieza, "Juan de Palafox", pp. 80-108.

40 Gil Sanjuán, "La sinceridad de fray Alonso de Santo Tomás”, p. 420.

${ }^{41}$ Coello, "Pasquines, libelos y corrupción en las Filipinas", pp. 113-145. 
del Conde Duque de Olivares (1643), lo que contribuyó a fomentar un antijesuitismo militante..$^{42}$ No sólo se les acusaba de participar en corruptelas y crímenes políticos, sino que atacaba a la obra evangelizadora llevada a cabo por la Compañía de Jesús en América y Asia.

Frente a tales acusaciones, ¿estaba la Junta de Regencia (denominada habitualmente Junta de Gobierno) dispuesta a financiar una empresa de conquista y colonización, liderada por la Compañía de Jesús, en un contexto de crisis galopante? Y, sobre todo, ¿era realista pensar que el proyecto del padre San Vitores podía financiarse sin la más mínima garantía de una contraprestación económica, simplemente para limpiar el buen nombre de la Compañía de Jesús frente a las críticas de sus enemigos herejes y protestantes? En cierto modo, los jesuitas acabaron utilizando ese mismo argumento -“la pobreza material"-para justificar sus pretensiones, ${ }^{43}$ aunque la primera reacción de la monarquía, como señala Baró, fue más bien decepcionante: se objetaba que había más almas que salvar en Filipinas, haciendo referencia a los problemas económicos y a los problemas logísticos que impedían asistir a las Marianas desde Manila. ${ }^{44}$

En lugar de ejercer como párrocos de indios, San Vitores consideraba que los jesuitas debían ocuparse de las misiones itinerantes, siguiendo el espíritu apostólico de Francisco Javier (1506-1552), formando grupos de vanguardia capaces de defender y propagar el evangelio en las Filipinas. ${ }^{45}$ En la Carta Anua

\footnotetext{
42 Moreno, "Obediencias negociadas", p. 680.

${ }_{43}$ En cierto modo, la publicación de la Historia de las islas Marianas (París, 1700), autorizada por el padre Charles Le Gobien (1653-1708), se justificó precisamente con esa intención: demostrar que los jesuitas eran tan ajenos a los bienes terrenales que por ese motivo decidieron evangelizar unas islas "pobres y marginadas” como las Marianas. RuBiÉs, "Prólogo", pp. 9-11.

44 Baró, "Redescubriendo a Diego Luis de San Vitores...", p. 21.

45 Ledesma, Noticias de los progresos, f. 7v.; Morales y Le Gobien, Historia de las islas Marianas, f. 10. Para un estudio de San Vitores como el nuevo "Francisco Javier", véase Strasser, Missionary Men, pp. 113-146.
} 
de 1633, y posteriormente, tras la fundación del presidio de San José de Zamboanga en 1635, el procurador Juan de Bueras (1583-1646) lamentaba la escasez de misioneros destinados en las residencias de Nauhan e Ilog, lo que había favorecido el aumento de la apostasía e idolatría. ${ }^{46}$ Por este motivo, el provincial Zapata decidió enviar refuerzos a la isla de Mindoro. A finales de 1663, el padre San Vitores se ocupó de la evangelización de los gentiles manguianes, edificando en ella las iglesias de María, San Ignacio y San Javier. ${ }^{47}$ La pobreza de los nativos hizo que el gobernador los exonerara del pago del tributo por espacio de diez años, lo que según el padre Diego de Oña no estuvo exento de críticas. ${ }^{48}$ Dichos manguianes carecían de "los vicios más comunes de otras naciones, embriaguez, hurtos, engaños, crueldad, que ni aun armas usan para defenderse". Curiosamente, estaban "exentos de idolatría, como de la secta de Mahoma, y otras supersticiones muy ordinarias en este archipiélago", lo que le permitía establecer comparaciones con los nativos de las Marianas. ${ }^{49}$ Posteriormente, San Vitores fue destinado al puerto de Cavite, donde se ocupó de visitar las cárceles y galeras. ${ }^{50}$

Entre 1664 y 1666 fue nombrado maestro de novicios en Manila y praefectus spiritus et studiorum en la Universidad y de varias congregaciones. ${ }^{51}$ Desde allí promovió las misiones populares y el mencionado acto de contrición, ya fuera en el interior de una iglesia o por las calles, incitando a una participación activa

\footnotetext{
${ }^{46}$ Juan de Bueras, SJ, “Mission de Samboangan en Mindanao", con fecha en Manila, 26 de mayo de 1636. ARSI, Philipp. 07-1, f. 276r. Véase también BlaNco, "Idolatry and Apostasy", pp. 115-130.

47 Zambrano, Diccionario bio-bibliográfico, vol. xIII, p. 778.

48 OÑa, Labor Evangélica. Segunda Parte, ff. 1483-1484r. Véase también Zambrano, Diccionario bio-bibliográfico, vol. xIII, p. 778.

49 García, Vida y martyrio, pp. 133-136.

50 Zambrano, Diccionario bio-bibliográfico, vol. xII, p. 778.

51 ARSI, Philipp. 4, ff. 49r.-57r. Véase también Zambrano, Diccionario biobibliográfico, vol. XIII, p. 778.
} 
y directa de los fieles. ${ }^{52}$ En 1664 el almirante Esteban Ramos regresó a Manila junto con cuatro filipinos que habían permanecido durante 26 años en las Marianas, víctimas del naufragio del galeón Nuestra Señora de la Concepción frente a la isla de Saipan (1638). ${ }^{53}$ Los náufragos saltaron de isla en isla hasta que algunos consiguieron regresar a las Filipinas. ${ }^{54}$ Durante su "exilio" en la isla de Guam habían aprendido la lengua chamorra, por lo que se convirtieron en los futuros intérpretes. En su informe de 1665 confirmaban que los isleños eran "gente dócil y afable, y que no tienen secta, ni ritos, ni otros vecinos que se las enseñen", concluyendo que la evangelización era empresa "de muy poca costa, pues basta, que con los religiosos vayan cantidad de veinte españoles, y otros tantos naturales de estas islas [...] por ser aquella gente muy pacífica, y sin borracheras". ${ }^{5}$

Resuelto a emprender aquella conquista espiritual, el futuro “apóstol de las Marianas” escribió un Memorial dirigido a su padre don Jerónimo de San Vitores de la Portilla (1596-1675), Marqués de la Rambla y consejero de Hacienda, con fecha en Manila, 29 de mayo de 1665, en el que argumentaba "los motivos para no dilatar más la reducción y doctrina de las islas de los Ladrones" ${ }^{56}$ Se trataba de un grupo de islas pequeñas habitadas por "gente sencilla y apacible sin ídolos, religión ni secta alguna ni adoran al sol ni a la luna ni a otra cosa criada solo se

\footnotetext{
52 Como apunta Broggio, "Sanvitores ne se limita pas à transplanter en Extrême-Orient des cérémonies déjà en usage dans la mère patrie: il conçut des techniques nouvelles qui tiraient profit de l'expérience acquise dans les missions intérieures". BROGGIO, "L'acto de contrición", p. 251.

53 Coomans, History of the Mission in the Marianas: 1667-1673, p. 5. Véase también FARReLL, History of the Northern Mariana Islands, p. 140.

${ }^{54}$ Maggs Bros, Bibliotheca Americana et Philippina, Parte III, Catálogo no 442, pp. 104-105.

55 AGI, Filipinas 82, N. 8, ff. $1 \mathrm{r}^{\circ}-2^{\mathrm{v}}$.

56 AGI, Filipinas 82, N. 8; AHN, Ultramar 562, ff. 956-961.
} 


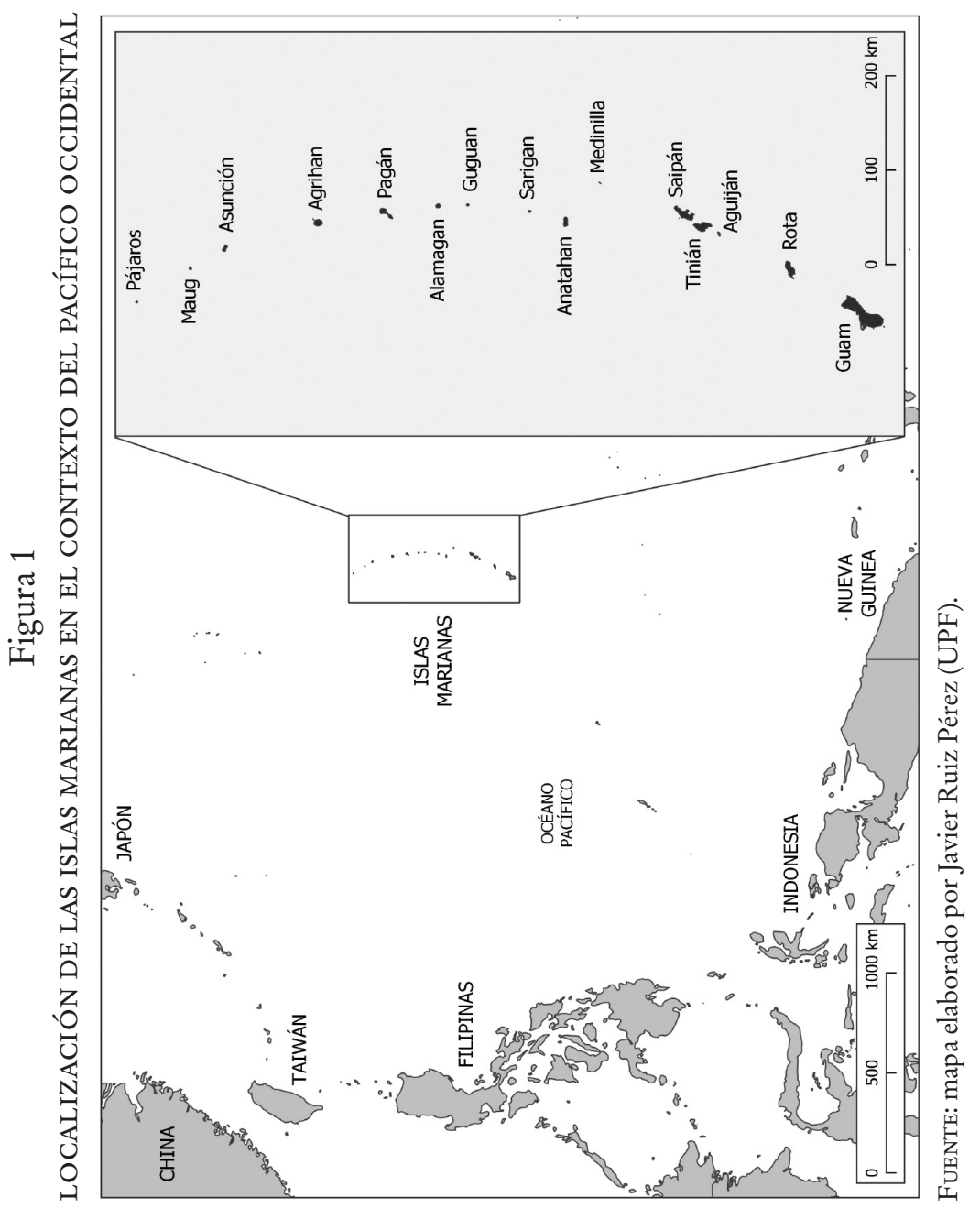


halla en ellos alguna reverencia y temor a sus difuntos". ${ }^{57} \mathrm{La}$ posibilidad de que ningún pecado original los hubiera corrompido se extendía como un leitmotiv para organizar una expedición. Además, insistía, los nativos de las islas de los Ladrones no habían tenido contacto con los musulmanes "que acá persiguen nuestras doctrinas y libres aun los naturales de esta infame secta de Mahoma". 58

Sin embargo, a las autoridades jesuitas de Manila les preocupaba la escasez de misioneros que padecía la provincia..$^{59}$ En enero de 1664, el padre Luis Pimentel (1612-1689) fue nombrado procurador en la corte de Madrid en sustitución del padre Antonio Abarca (1610-1660), fallecido en las inmediaciones de Acapulco. ${ }^{60}$ A su llegada, entre 1666 y 1667, presentó un Memorial al Consejo de Indias solicitando 45 nuevos sujetos para las islas Filipinas. ${ }^{61}$ Dicha solicitud estaba apoyaba por las

57 Jerónimo San Vitores de la Portilla, Memorial de Jerónimo San Vitores de la Portilla, del Consejo de Hacienda, sobre que su bijo Diego Luis de San Vitores, de la Compañia de Jesús, le ha remitido un memorial sobre la importancia de la evangelización de las Marianas y la necesidad de que se envien alli religiosos, ca. 1666. "Expediente sobre la evangelización de las islas de los Ladrones o Marianas", en AGI, Filipinas 82, N. 8, 26/03/1669; AHN, Diversos-Colecciones, leg. $27, \mathrm{n}^{\circ} 35$, ff. $1 \mathrm{r}$. $-2 \mathrm{v}$.

58 ARSI, Philipp. 14, f. 57r.

59 Astrain, Historia de la Compañía de Jesús, vol. vi, pp. 808-809.

60 De La Costa, The Jesuits in the Philippines, pp. 435-436; Salvá, "Misioneros jesuitas a Filipinas", pp. 522-523. Según Fechner, los padres Pimentel y Abarca formarían parte del tercer grupo de procuradores, esto es, aquellos "que obran por interés de la Compañía en las cortes, por ejemplo, el procurador en corte de Madrid o el procurator generalis en la Santa Sede". Fechner, "Las tierras incógnitas", p. 32.

${ }^{61}$ Desde finales del siglo XVI, los procuradores elegidos por las congregaciones provinciales se convirtieron en figuras capitales para entender la organización radial de la Compañía desde el centro (Roma) hacia sus provincias. FecHNER, "Las tierras incógnitas", pp. 31-32. Una de las tareas principales de los procuradores enviados a intervalos regulares de seis años a Madrid y a Roma consistía en reclutar misioneros españoles, o en su defecto, extranjeros de las provincias de Austria, Bohemia, Germania y Bélgica, informando al padre 
fuerzas vivas del archipiélago, a saber, el arzobispo Millán de Poblete, el cabildo municipal en pleno, el gobernador Manrique de Lara y los oidores de la Audiencia de Manila, quienes entre 1659 y 1661 escribieron cartas de apoyo a la Compañía de Jesús. Con todo, el gobernador se mostró reticente a enviar jesuitas a las Marianas, sobre todo por la distancia que las separaba de Manila y la dificultad de su abastecimiento.

A pesar de las dificultades, los superiores aceptaron el proyecto debido a varios factores, y no simplemente, como se ha repetido hasta la saciedad, por el "entusiasmo y fervor del padre San Vitores”. En un contexto político de crisis, los españoles abandonaron las principales plazas de las Molucas, Mindanao y Joló, lo que limitó la labor evangelizadora y misionera de los jesuitas. Si a eso añadimos la política aislacionista nipona o sakoku (5/7/1639), que imposibilitaba a los ignacianos y a las órdenes mendicantes la fundación de nuevas misiones en tierras niponas, no debería extrañarnos que la Compañía de Jesús viera con buenos ojos el proyecto misionero de San Vitores, que pretendía continuar las misiones apostólicas que Francisco Javier había llevado a cabo en los territorios de China y Japón (y continuadas por los jesuitas italianos Alessandro Valignano y Mateo Ricci) en las "pobres y olvidadas" islas Marianas. ${ }^{62}$

general en Roma de los asuntos más urgentes (en forma de "postulados") de la provincia jesuítica. Martínez-Serna, "Procurators and the Making of the Jesuits", pp. 207-208; FeCHNER, "Entre el pragmatismo local”, p. 79. Asimismo, se encargaban de adquirir reliquias, libros, ropa, vino, así como los elementos de liturgia necesarios para sus iglesias provinciales. Martínez-Serna, "Procurators and the Making of the Jesuits", pp. 194-201.

${ }^{62}$ Sobre la influencia de Francisco Javier en la idea jesuita de misión, véase Carrocera, "Ideas misionológicas de San Francisco Javier", pp. 644-654; BurriezA, Jesuitas en Indias, pp. 79-80. 
Diversos autores han puesto de relieve las palabras de Lucas el evangelista (4:18) como justificación del escaso interés de los gobernadores de Filipinas en su colonización. ${ }^{63}$ En contraste con las Molucas, donde se cultivaban especias tan apreciadas en los mercados europeos como la nuez moscada y el clavo, las Marianas carecían de "género ninguno" que pudiera atraer a los comerciantes españoles. ${ }^{64} \mathrm{~A}$ esta "pobreza material” se añadía que estaban desprovistas de una ruta que permitiese trasladar religiosos y bastimentos desde Manila sin correr ningún riesgo ${ }^{65}$ Por el contrario, la ruta Acapulco-Manila era mucho más segura ya que los galeones solían avituallarse en las Marianas antes de su llegada a las Filipinas.

Sin embargo, San Vitores consideraba que, además de los escasos recursos, los nativos estaban sumidos en una "pobreza espiritual" que hacía imperativa la intervención del monarca. Su principal valedor en la corte fue siempre su propio padre, don Jerónimo de San Vitores, quien presentó el citado Memorial (ca. 1665) al secretario del Consejo de Indias, don Alonso Fernández de Lorca. Los argumentos eran esencialmente los mismos que su hijo había manifestado a las autoridades políticas de Manila. La causa principal para la conquista y conservación de las islas Filipinas había sido el estado de abandono en que se encontraban las islas y sus habitantes, por lo que era necesario "alumbrar las gentes que habitan estas regiones en las tinieblas de su ceguedad

${ }^{63}$ Coello, "El Fénix en las Marianas (1747)”, p. 782; Atienza, "La evangelización de las 'pobres' islas Marianas", p. 194; AtıEnzA, “A Mariana Islands History Story”, pp. 13-29.

${ }^{64}$ López de Velasco, Geografía y descripción universal de las Indias (157174), citado en PeÑa Filıu, “Alimentación y colonialismo en las islas Marianas", cap. 3.

${ }^{65}$ El primer patache directo desde Manila a Guam no zarpó sino hasta 1683. Coello, Jesuits at the Margins, p. 89. 
y cautiverio del demonio". ${ }^{66}$ Los poderosos y acaudalados, por su razón de serlo, estaban obligados a utilizar sus recursos para auxiliar a los “miserables", esto es, a los más pobres (Juan Luis Vives, De subventione pauperum, 1526). ${ }^{67} \mathrm{El}$ rey Felipe IV, en su lecho de muerte, tenía, pues, el deber moral de acudir al rescate de tantos indios desamparados que vivían sin doctrina, so pena de atraer para sí los castigos divinos. Como reza el adagio latino, vulnerant omnes, ultima necat (todas hieren, la última mata). A continuación, San Vitores se entrevistó con el arzobispo Poblete para poder organizar una misión religiosa a las islas. Pero las dificultades económicas de la hacienda real, y sobre todo las escasas perspectivas de rentabilidad de las islas, desaconsejaban acometer semejante empresa.

A diferencia de las Bisayas, donde los españoles encontraron recursos suficientes para justificar su presencia en las islas, ${ }^{68}$ el gobernador saliente de las Filipinas, don Sabiniano Manrique de Lara, describió las Marianas como un locus horribilis donde solo había pescado y alimentos crudos que comer. Por este motivo, y además, por la presumible hostilidad de los nativos, Manrique de Lara desaconsejaba la conquista y conversión del archipiélago, profetizando que "aunque a los principios los reciban [a los misioneros españoles] de paz y les hagan agasajos, cuando se les antoje darán sobre ellos y los degollarán”. ${ }^{69}$ A pesar de ello,

${ }^{66}$ J. SAn Vitores, Memorial de Jerónimo San Vitores de la Portilla. "Expediente sobre la evangelización de las islas de los Ladrones o Marianas", en AGI, Filipinas 82, N. 8, 26/03/1669.

67 MacCormack, “Conciencia y práctica social...”, pp. 69-99.

${ }^{68}$ La Relación de las islas Filipinas, finalizada en 1654, fue escrita por el padre Francisco Combés (1620-1665), para informar al nuevo gobernador y capitán general de las Filipinas, don Sabiniano Manrique de Lara (1653-1663), acerca de las particularidades (etnográficas, geográficas, botánicas) de las Filipinas, así como de sus riquezas potenciales (naturales, morales), con el fin de ayudarle a diseñar las políticas a seguir. Coello, "Against Muhammad's perfidy".

69 "Carta de Sabiniano Manrique de Lara al secretario don Alonso Fernández de Lorca, informando sobre la reducción de las islas de los Ladrones", 
los jesuitas aspiraban a ganar pacíficamente aquellas islas para el catolicismo, convirtiendo "aquella selva inculta de malezas" en un "hermoso y ameno jardín" (locus amoenus). ${ }^{70}$

Su sucesor en el cargo, don Diego de Salcedo (1663-1668), tampoco quiso hacerse cargo de la misión. ${ }^{71}$ Además, es de suponer que las tensas relaciones que mantenía con el arzobispo Miguel de Poblete, de sobra conocidas, condicionaran su negativa. ${ }^{72}$ A diferencia de los virreinatos del Perú y Nueva España, los vecinos de Manila eran un grupo social minoritario escasamente interesado en llevar a cabo costosas campañas de conquista que consideraban arriesgadas y de escaso valor. Eran pocos y se dedicaban principalmente al comercio de productos orientales entre Filipinas y Acapulco. ${ }^{73} \mathrm{El}$ repliegue de las fuerzas españolas en Filipinas impedía financiar desde Manila nuevas campañas de conquista y evangelización. ${ }^{74}$

La muerte de Felipe IV (1621-1665) planteó por primera vez serias dudas sobre la capacidad de la Monarchia Universalis para continuar sosteniendo la integridad del entramado imperial. ${ }^{75} \mathrm{El}$ poder del águila bicéfala recayó sobre los hombros de la viuda de Felipe IV y madre de Carlos II, la archiduquesa Mariana de Austria (1634-1696), y de su maestro espiritual, confesor e inquisidor general (1666), el jesuita austríaco Juan Everardo Nithard

\footnotetext{
Alhaurín de la Torre, 20 de diciembre de 1667. AGI, Filipinas leg. 82, nº 8, citado en PeÑa FILIU, "Alimentación y colonialismo en las islas Marianas", cap. 3. 70 ARSI, Filipinas 13, ff. 111-118, citado en LÉvesque, History of the Micronesia, vol. 6, pp. 205-206.

${ }^{71}$ Según el testimonio del padre Morales, “este personaje se declaró abiertamente contrario al proyecto negándose a toda cooperación, por lo que los superiores rogaron al padre [San Vitores] que no le hablase más de ello por temor de que malquistándose con él, diese esto lugar a algún disgusto en que la Compañía saliese perjudicada". Morales, Historia de las islas Marianas, f. 19.

72 Cabrero, Historia General de las Filipinas, pp. 244-246.

73 García-Abásolo, "La primera exploración del Pacífico", p. 28.

${ }^{74}$ Coello, "No es esta tierra para tibios", pp. 57-58.

75 Fernández Albaladejo, La crisis de la Monarquía, p. 395.
} 
(1607-1681), quien utilizó su amistad e influencia como "favorito" para apoyar a sus hermanos de religión. ${ }^{76}$ Si como apunta Pérez Samper, las reinas eran soberanas de las almas del reino, no es menos cierto que sus confesores, como Nithard, ostentaban un gran poder sobre aquellas almas de estirpe regia. Eran esposas de reyes y madres de futuros reyes y reinas. ${ }^{77}$ Por ello, controlar este tipo de conciencias, según Lozano Navarro, era fundamental para los objetivos de la Compañía de Jesús. ${ }^{78}$

La debilidad política y económica del imperio español después de la firma del tratado de paz entre Madrid y las Provincias Unidas en Münster, Westfalia (1648), y la Paz de los Pirineos (1659), unida a las conexiones del padre Nithard y a su posición clave en la corte española, favoreció indirectamente los proyectos misionales de los jesuitas en Filipinas, situándolos en la órbita política de los Habsburgo. Los principales apoyos vinieron de la reina gobernadora Mariana de Austria, quien desde el comienzo defendió el proyecto misional del padre San Vitores. Así, el 24 de junio de 1665, la reina Mariana envió una Real Cédula en la que apoyaba el proyecto de San Vitores y bendecía su misión, asignando 21000 pesos a la subvención y defensa de las islas. Un gesto que pretendía devolver al imperio la protección divina que parecía haber perdido. En julio de 1667, los jesuitas, agradecidos, cambiaron el nombre de islas de los Ladrones por el de Marianas, en honor de la Virgen María y de la reina gobernadora. ${ }^{79}$

76 Lozano Navarro, La Compañia de Jesús, pp. 297-324; Burrieza, “Las Glorias del segundo siglo (1622-1700)”, pp. 169-171.

77 Pérez Samper, "Infantas y reinas”, pp. 9-16.

78 Julián J. Lozano Navarro, “Confesionario e influencia política. La Compañía de Jesús y la dirección espiritual de princesas y soberanas en el barroco”, ponencia presentada en el Congreso Internacional Los Jesuitas. Religión, Política y Educación (Siglos XVI-XVIII), Universidad Pontificia, Comillas, 20 de junio de 2011. Véase También Álvarez-Osorio, “iQuieren los españoles definir!", p. 63.

79 AGI, Filipinas 82-2-29. 
Ante la oposición del gobernador Salcedo a enviar un patache directamente desde Cavite a las Marianas, el 7 de agosto de 1667, San Vitores salió del puerto de Cavite en el patache San Diego con dirección a México, acompañado del padre palentino Tomás Cardeñoso (1639-1717) y del hermano donado Felipe Sonsón (1611-1684)..$^{80}$ El objetivo era obtener los fondos necesarios para subvencionar la misión a la isla de Guam, y a la vuelta, inaugurar oficialmente la misión. ${ }^{81}$

San Vitores llegó a Acapulco el 14 de enero de 1668 y se entrevistó con el virrey de Nueva España, Marqués de Mancera, a quien el padre Francisco Ximénez (o François Guillot o Jilot) (1601-1686), prefecto del reputado Colegio Máximo de San Pedro y San Pablo (1666-1673), había convencido para que concediera a los jesuitas el privilegio de evangelizar las Islas Marianas y las Californias. ${ }^{82}$ No en vano el padre Ximénez era su confesor, así como el de la marquesa consorte de Mancera, doña Leonor Carreto (1616-1673), por lo que accedió a apoyar a los jesuitas con 10000 pesos de las Cajas Reales a cuenta del situado de Filipinas, según lo establecido por el rey Felipe IV, proporcionándoles diversos sirvientes y otros donativos. ${ }^{83}$

La persistencia del padre San Vitores hizo que en abril partiera de vuelta a Guam en el patache San Diego, una alegoría de "la Nave de la Iglesia Militante" con cinco jesuitas: los padres Tomás Cardeñoso, el malagueño Luis de Medina (1636-1670),

${ }^{80}$ Coomans, History of the Mission in the Marianas: 1667-1673, p. 2. Los donados eran aquellos que sin haber hecho los votos de una orden religiosa, servían como ayudantes y auxiliares a los sacerdotes, permaneciendo como laicos en el sentido estricto del término. SCHUMACHER, "Early Filipino Jesuits: 1593-1930", p. 273.

81 Morales y Le Gobien, Historia de las islas Marianas, f. 21.

${ }^{82}$ Zambrano, Diccionario bio-bibliográfico, vol. viII, pp. 224-256.

83 AGI, Filipinas 82 N.10. Véase también García, Vida y martyrio del venerable padre Diego Luis de Sanvitores, p. 184; Coomans, History of the Mission in the Marianas: 1667-1673, p. 3; Zambrano, Diccionario bio-bibliográfico, vol. XIII, p. 778. 
el almeriense Pedro de Casanova (1641-1694), el vallisoletano Luis Martín de Morales (1641-1716) y el hermano escolar Lorenzo Bustillo (1642-1716), quienes salieron de Acapulco el 23 de marzo de 1668, llegando a las Marianas el sábado 16 de junio del mismo año. ${ }^{84}$ No hay que olvidar que la popularidad de Francisco Javier en México y Filipinas era como un espejo en el que se reflejaron los primeros misioneros de las Californias y de las Islas Marianas. ${ }^{85}$

El 2 de febrero de 1669, los jesuitas edificaron el primer templo en San Ignacio de Agaña, así como su residencia en la nueva plaza de armas de la que sería su capital. En julio solicitaron al gobernador don Manuel de León (1669-1677), que iba de camino a Filipinas a bordo del galeón San Joseph, que les proporcionara algunos hombres, municiones y armamento necesario para proteger la misión. La oposición de los misioneros a la promiscuidad de los chamorros, así como la destrucción de los ídolos, provocó la creciente hostilidad de los nativos hacia los religiosos. ${ }^{86} \mathrm{Y}$ cumpliendo así el pronóstico del exgobernador Manrique de Lara, el 29 de enero de 1670, el padre Luis de Medina era asesinado en una aldea de la isla de Saipan, a tres millas de la isla de Tinián, por un tal Poyo, a quien llamaban "el matador” (luego bautizado como Luis), y su cómplice, llamado Daon (luego bautizado como Vidal), contando 33 años de edad. ${ }^{87}$

${ }_{84}$ ARSI, Philipp. 4, f. 60r; ARSI, Philipp. 13, ff. 5r.-8v.

85 Alegre, Historia de la Compañía de Jesús, vol. iII, pp. 298, 301-302. En marzo de 1671 los jesuitas trajeron desde Nueva España una imagen de Francisco Javier, donde San Vitores había promovido una congregación en su honor. Alegre, Historia de la Compañia de Jesús, vol. III, pp. 249, 301.

${ }^{86}$ AGI, Filipinas, leg. 10, ramo 1, no 2; ARSI, Philipp. 13, ff. 37r.-39r. Véase también Coello, Jesuits at the Margins, p. 35.

87 Según la lista de mártires, el padre Medina murió "in odium sacram baptismati et fidei christianae praedicationis a barbari". AHCJC, carp. "EI.b-9/5/2. Martirios, naufragios, \&.”, contenida en EI/b-9/5/1-7. "Martirios y varones ilustres". Hojas sueltas). ARSI, Philipp. 13, ff. 50v.-52r.; Ledesma, "Noticias de los progresos de nuestra santa fe", f. 10r. 
Con él murió Hipólito de la Cruz, natural de las Islas de los Pintados o Visayas (Cebú) y virtuoso del arpa. ${ }^{88}$ El proyecto de "evangelización pacífica" de San Vitores, conceptualizado sin la presencia de soldados ni presidios, quedaba seriamente comprometido.$^{89}$ A partir de entonces, la escasez de recursos aumentó y los misioneros solicitaron el envío de nuevas provisiones a los congregantes de San Francisco Javier, en la ciudad de México, y a su protector, el virrey (1669). ${ }^{90}$

Entretanto, el 5 de marzo de 1670 tuvo lugar un milagroso suceso en la capilla del colegio jesuita de San Ildefonso, en México. La imagen de San Francisco Javier empezó a sudar copiosamente, y su rector, el padre Joseph Vidal, a la sazón procurador de las Islas Marianas, atribuyó dicho sudor a los trabajos y sufrimientos que los misioneros jesuitas estaban padeciendo en el archipiélago mariano. ${ }^{91}$ Los fieles respondieron con cuantiosas limosnas al "sudor sagrado" del santo, lo que sin duda favoreció que religiosos respetados, como los jesuitas, se situaran en una posición de privilegio frente al resto de órdenes religiosas. Las peticiones del "nuevo Francisco Javier" $(1669,1670)$ parecían estar dando sus frutos. Paralelamente, los primeros informes escritos por los misioneros y procuradores jesuitas, como la "Noticias de los progresos de nuestra santa fe en las islas Marianas, llamadas antes, de los Ladrones", del padre procurador (1668-1671) y luego provincial Andrés de Ledesma (1671-1675), ${ }^{92}$ tenían una función propagandística que pretendía

${ }_{88}$ Astrain, Historia de la Compañia de Jesús, vol. vi, p. 817.

${ }^{89}$ ARSI, Philipp. 13, ff. 76r.-76v.

90 San Vitores, Memorial que el P. Diego Luis de San Vitores (...) remitió a la Congregación del glorioso apóstol de las Indias, San Francisco Javier, de la ciudad de México, pidiendo le ayuden y socorran para la fundación de la misión de dichas Islas (México, 1669), citado en Zambrano, Diccionario biobibliográfico, vol. XII, p. 793; Morales, Historia de las islas Marianas, f. 97r.

${ }^{91}$ Zambrano, Diccionario bio-bibliográfico, vol. xIII, p. 782.

92 ARSI, Philipp. 2-II, f. 360r. 
popularizar su labor y, sobre todo, ayudar a recaudar fondos para las misiones oceánicas de Asia-Pacífico. ${ }^{93}$

\author{
DE “LAS COSAS TOCANTES A LAS ISLAS MARIANAS” \\ EN LA NUEVA ESPAÑA (1671-1672)
}

Como señala Fechner, el procurador es, dentro de la administración jesuita, un término muy polivalente. ${ }^{94}$ Como procurador de la congregación de San Francisco Javier, Vidal Figueroa era responsable de la contabilidad y de la compra de bienes para la misión de las Marianas, y por lo tanto, sus funciones eran meramente económicas. En la carta que escribió al padre Joseph Vidal de Figueroa, procurador de las Marianas, a los hermanos de la Santa Caridad de Sevilla y a su protectora, la reina gobernadora Mariana de Austria, con fecha en Guam, 21 de mayo de 1671, San Vitores solicitaba ayuda económica para el establecimiento de un colegio. ${ }^{95}$

Como sucedió en la conquista y colonización de América, la incorporación de las Islas Marianas al imperium cristiano se efectuó de manera violenta. No fue sino hasta la muerte de Luis de Medina (1670) cuando la reina Mariana, a petición de San Vitores, dictó dos nuevas Reales Cédulas: la primera, con fecha en Madrid, 12 de agosto de 1671, en la que ordenaba al virrey de Nueva España que proporcionara a los jesuitas de las Marianas la protección necesaria para salvaguardar el futuro de la misión; la segunda, con fecha en Madrid, 16 de noviembre de 1671, por la que ordenaba al virrey enviar 200 soldados pampangos para que se integraran en el futuro presidio de Guam. ${ }^{96} \mathrm{El}$

\footnotetext{
${ }_{93}$ Barret, "Preface", pp. 6-8.

94 Fechner, "Las tierras incógnitas", p. 32.

95 Astrain, Historia de la Compañia de Jesús, vol. vi, p. 817.

96 AGN, Cédulas Reales, vol. 12, exp. 128, ff. 325-327. Dicha Real Cédula fue confirmada en otra, con fecha en Madrid, 10 de junio 1672, ordenando que se enviaran 18 soldados para la protección de los jesuitas de las Marianas. AGN,
} 
martirio del padre Medina se convirtió en la expresión máxima de su identificación con la crucifixión de Jesucristo. Ciertamente el deseo de imitarlo no era exclusivo de los jesuitas, sino que se extendía a los misioneros de todas las órdenes. Pero la fuerza simbólica de la muerte de Medina “en acto de servicio” aceleró la construcción del presidio y la llegada de soldados desde la Nueva España, al mismo tiempo que tuvo un efecto multiplicador en los sucesivos martirios de jesuitas $(1676,1684)$ que se sucedieron en las islas. ${ }^{97}$

En 1670 ningún galeón español se aproximó a las costas de Guam. ${ }^{98}$ Un año después, el 10 de junio de 1671, llegó al puerto de Umatac el patache Nuestra Señora del Buen Socorro con nuevos misioneros: los padres Francisco Solano y Diego de Noriega

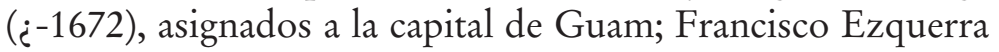
(1644-1674), asignado a la isla de Rota, y el cartógrafo Alonso López (1646-1675), destinado a la isla de Tinián, así como un destacamento de soldados y provisiones, especialmente ganado (cerdos, vacas, pavos, palomas) y equipamiento agrícola y culinario, que aliviaron la escasez del año anterior. ${ }^{99}$

Durante estos primeros años de la misión, uno de los problemas principales fue el abastecimiento de productos de primera necesidad, como el vino, harina, trigo, arroz, sin olvidar los aperos de labranza, considerados esenciales para garantizar su autosuficiencia. Los chamorros se alimentaban fundamentalmente de pescado, pan de fruta (rima y, duc-duc), y ocasionalmente,

Cédulas Reales, vol. 13, exp. 56, ff. 135-136; exp. 115, ff. 275-276. Véase también Hezel, "From Conversion to Conquest”, p. 122.

97 Dicho presidio, instrumento clave de población en espacios de frontera, era claramente de inspiración novohispana. Desde la llegada del padre Gonzalo de Tapia a la villa de San Felipe y Santiago de Sinaloa en 1591, los jesuitas consolidaron el sistema de misión-presidio en el septentrión novohispano. ARNAL, "El presidio", pp. 107-128.

98 Coomans, History of the Mission in the Marianas: 1667-1673, pp. 59-60.

99 ARSI, Philipp. 13, ff. 95-110; 156-159v. 
arroz. ${ }^{100}$ Los españoles introdujeron vacas, cerdos, pollos, palomas y aperos de labranza. En su Gobierno politico de la agricultura (1618), Lope de Deza (1564-1626) ya había denunciado la ignorancia de los indios americanos, "tan perezosos y negligentes en ellas como eran y aún como son”, en todo lo que hacía referencia a los beneficios de la agricultura en la vida pública. ${ }^{101}$ Por esta razón es necesario tener en cuenta, como ha señalado Peña Filiu, no sólo la "conquista espiritual” de las Marianas, sino también la "conquista gastronómica” que se produjo a raíz del proyecto jesuita de San Vitores. ${ }^{102}$

Mientras tanto, la Junta de Gobierno dictó una serie de Reales Cédulas por las que mostraba claramente su apoyo al proyecto del padre San Vitores: en la primera, con fecha en Madrid, 24 de octubre de 1671, se ordenaba al virrey de México que no se pidieran "fletes ni otros derechos" a los géneros destinados a las misiones de las Islas Marianas en el puerto de Acapulco; ${ }^{103}$ en la segunda, con fecha en Madrid, 14 de noviembre de 1671, se autorizaba al misionero jesuita a cruzar de una isla a otra del archipiélago con el fin de fomentar la conversión de los nativos, y en la tercera, con fecha 16 de noviembre de 1671, se ordenaba al virrey enviar a las Marianas a todos los religiosos jesuitas que pudiere, aprovechando las naos que partían desde Acapulco hacia las Filipinas. ${ }^{104}$

El 10 de febrero de 1672, el hermano coadjutor Manuel Duarte (1624-1689), procurador general de las misiones de las

100 Coomans, History of the Mission in the Marianas: 1667-1673, p. 10.

101 Lope DE DezA, "Sobre la dignidad de la agricultura (1618)", en Gobierno político de la agricultura, Madrid, ICI, p. 191, citado en Fernández AlbalaDEJO, La crisis de la Monarquía, pp. 706-711.

102 PeÑa Filiu, “Alimentación y colonialismo en las islas Marianas”, cap. 3.

103 "Real Cédula de la Reina Mariana de Austria al Virrey de la Nueva España”, con fecha en Madrid, 24 de octubre de 1671. ARSI, Philipp. 13, f. 81r. 104 AGN, Cédulas Reales, vol. 12, exp. 26, ff. 321-322. 
islas Filipinas y Marianas, ${ }^{105}$ remitió una copia de la carta del padre San Vitores, con fecha 12 de agosto de 1671, al virrey de la Nueva España, con el fin de proveerle de "las cosas que necesitaren". ${ }^{106}$ Como señala Fechner, "las procuradurías de las misiones eran las centrales de aprovisionamiento para las provincias ultramarinas y se hallaban en los puertos de embarque". En el caso del hermano Duarte, su función como procurador de misiones era doble: la negociación con las autoridades y la compra de bienes. ${ }^{107} \mathrm{Sin}$ embargo, la salida de los recursos necesarios desde Acapulco se veía afectada por una serie de irregularidades, como era el cobro de derechos y fletes, que perjudicaba el abastecimiento de la misión, lo que obligó a la reina gobernadora a intervenir. ${ }^{108}$ Para conseguir los bastimentos, así como el capital necesario para comprarlos, San Vitores solía utilizar un "poder especial" de la reina gobernadora que entraba en contradicción con el "poder general" que los procuradores de la provincia jesuita de la Nueva España utilizaban regularmente para "dar medio y poner en cobro lo que su Majestad mandare se dé en esta Real Caja para aquellas misiones".

La persona clave era, por aquel entonces, el procurador Duarte, quien escribió una carta al padre provincial de la Nueva España, Andrés de Cobián (1671-1673), ${ }^{109}$ con fecha 22 de fe-

${ }^{105}$ Para una biografía sobre el padre Manuel Duarte (1624-1689), véase ZAMBRANO, Diccionario bio-bibliográfico, vol. vI, pp. 368-371.

106 ARSI, Philipp. 13, ff. 71r.-71v.

107 Fechner, “Las tierras incógnitas", p. 32.

108 PeÑa Filıu, "Alimentación y colonialismo en las islas Marianas", cap. 3. Cobrar derechos aduaneros en Acapulco era una práctica habitual. El 2 de mayo de 1670, el procurador general de los jesuitas de Filipinas, Andrés de Ledesma, escribió un Memorial al presidente de la Casa de Contratación de Sevilla, solicitándole que no se cobrasen derechos de los géneros y demás cosas que el procurador Luis Pimentel pensaba llevar consigo de vuelta a Filipinas. AGI, Filipinas 82, N. 12.

109 Para una biografía sobre el padre Andrés de Cobián (1615-1673), véase Zambrano, Diccionario bio-bibliográfico, vol. v, pp. 247-265; Alegre, Historia de la Compañia de Jesús..., vol. III, p. 313. 
brero de 1672, por la que lamentaba esta duplicidad de poderes. Y lo justificaba en la caducidad del poder del padre San Vitores, "porque el poder del dicho padre que yo tengo en que superior es instantáneo y no tiene firmeza, porque hoy es superior y mañana no; o se moriría con que cesa dicho poder". ${ }^{110}$ Asimismo, puesto que la mayoría de los diez misioneros que operaban en las Marianas eran sujetos de la provincia de las Filipinas, y no de la Nueva España, consideraba que debía corresponder a la primera proveer de todo lo necesario a los misioneros. Con todo, el hermano Duarte se defendía de las acusaciones de desamparar las islas Marianas, argumentando que tanto él como el padre provincial (1668-1671), el novohispano Pedro de Valencia (1593-1673), ${ }^{111}$ les habían ayudado generosamente, con muchos miles de pesos, de "esta Real Caja". Sin embargo, la respuesta del padre Joseph Vidal fue contundente. Así,

[El padre ministro Joseph Vidal] dice que yo [hermano Duarte] no tengo que ver ni que entrometerme en cosas que toquen al padre San Vitores y su misión, porque a su reverencia es a quien le toca, que aquellos padres no son de la Provincia de Filipinas, que la dicha Provincia no les ha dado nada, que tiene poder del padre San Vitores a los cuales puntos pon tanto son de motivo y la obligación que me corresponde satisfaré brevemente en nombre de su Provincia. ${ }^{112}$

En el epígrafe anterior aparecen claramente dos problemas de gestión. El primero, más general, se refiere al solapamiento de las

110 AGN, Jesuitas I, c.18, leg. 1-11, exp. 58, f. 205r.

111 Entre 1665 y 1668, el padre Valencia había sido rector del Colegio Máximo. Sobre el padre Valencia (1582-1671), véase ARSI, México 17, ff. 333r.-337v.; Alegre, Historia de la Compañía de Jesús..., vol. III, pp. 296-306.

112 AGN, Jesuitas I, c. 18, leg. 1-11, exp. 58, f. 205r. No fue sino hasta 1679 que el archipiélago quedó bajo la jurisdicción del virreinato de la Nueva Españadel que dependería económicamente- y de la Audiencia de Filipinas, formando parte de los territorios españoles de ultramar durante más de dos siglos. 
competencias entre los diferentes “procuradores” de la Nueva España; el segundo, más específico, a las tensiones existentes entre el procurador Joseph Vidal de Figueroa y los superiores (rector, provincial) respecto a la financiación de la misión de las Marianas. ¿Correspondía a las Filipinas o a la Nueva España el financiamiento de las Marianas? De acuerdo con el padre Vidal, no había ninguna duda: los jesuitas mexicanos debían velar por la misión de las Marianas, dada la imposibilidad de que sus cofrades pudieran enviarles ningún socorro desde Manila. ${ }^{113}$

Según el padre Joseph Vidal, el anterior procurador general de la Compañía de Jesús en Filipinas, el hermano Francisco Vello (o Bello, 1605-1671), ${ }^{114}$ siempre le había dado cuenta puntualmente de "todos los negocios que se ofrecían tocantes a las islas Marianas”, prevaleciendo su "poder especial” por encima del poder general de la provincia mexicana que ostentaba el procurador. ${ }^{115}$ Dicho poder general era posterior al "poder especial” de San Vitores y abarcaba "a todos los colegios, casas, sujetos, misioneros de las Marianas”. ${ }^{116}$ Sin embargo, la utilización del poder general que según Vidal ostentaba el procurador Vello (y por ende, el procurador Duarte), pero que nunca había utilizado, le hubiera obligado a derivar recursos a otras misiones del virreinato mexicano, como las existentes entre los indios de la nación tarahumara. ${ }^{117}$

En 1672 el padre superior (¿indígena?) de aquellas misiones, Jerónimo de Figueroa (ca.1605-1683), SJ, destacado en la región desde la década de 1640, escribió al provincial Andrés de Cobián, antiguo misionero de indios en el Colegio de Pátzcuaro,

113 AGN, Jesuitas I, c. 18, leg. 1-11, exp. 58, f. 205v.

114 Para una pequeña biografía del hermano Vello, véase Zambrano, Diccionario bio-bibliográfico, vol. XIV, pp. 650-656; Descalzo Yuste, "La Compañía de Jesús en Filipinas (1581-1768)”, p. 779.

115 ARSI, Philipp. 13, f. 79v.

116 AGN, Jesuitas I, c. 18, leg. 1-11, exp. 58, f. 205r.

117 ARSI, México 17, ff. 286r.-289v. 
provincia de Michoacán, ${ }^{118}$ solicitándole que aumentara el número de padres de estas nuevas misiones del noroeste novohispano, relegando aquellas otras de pocos indios, como las Islas Marianas. ${ }^{119}$ Esta razón explicaría las cifras, a todas luces exageradas, del número de nativos chamorros que vivían en aquellas islas del Pacífico, así como de los bautismos efectuados por los primeros jesuitas. Mientras que San Vitores apuntaba la cifra de 30000 nativos bautizados, los hagiógrafos, como Francisco García, elevaban la cifra hasta $50000 .{ }^{120}$

El año 1673 fue "feliz y memorable" para la misión de la Sierra Tarahumara, con nueve cabeceras de misión fundadas en poco tiempo. ${ }^{121}$ Con todo, el desarrollo y consolidación de las misiones jesuitas sólo podía mantenerse, al menos en un primer momento, mediante el patrocinio de la monarquía y de un sistema de mecenazgo particular que no admitía mucha competencia. ${ }^{122}$ Durante la XVII congregación provincial mexicana (noviembre de 1668) se promovió la beatificación de los ocho jesuitas que murieron en la rebelión de los tepehuanes de 1616, situándolos al mismo nivel que los tres jesuitas martirizados a finales del siglo Xvi en Japón. ${ }^{123}$ Quedaba claro, pues, que no todos los jesuitas estaban de acuerdo en invertir recursos materiales y humanos en unas islas tan remotas y ajenas a la Nueva España como las Marianas, especialmente cuando la Compañía estaba extendiendo su radio de acción en las misiones septentrionales

118 Alegre, Historia de la Compañia de Jesús, vol. III, pp. 304, 313; ZAMBraNo, Diccionario bio-bibliográfico, vol. v, pp. 247-265.

119 ARSI, México 17, f. 331r.

120 Zambrano, Diccionario bio-bibliográfico, vol. xiII, p. 782. Sin embargo, otras fuentes, como la del padre Coomans, señalan otra sensiblemente inferior: 20 000. Coomans, History of the Mission in the Marianas: 1667-1673, p. 24.

121 Alegre, Historia de la Compañía de Jesús, vol. III, p. 314. Véase también Gerhard, The North Frontier of the New Spain, p. 187.

122 Montes González, "Reflexiones sobre las misiones jesuíticas en el Noroeste novohispano”, p. 212.

123 Alegre, Historia de la Compañia de Jesús, vol. III, pp. 398-399. 
de Nueva Vizcaya, Sinaloa y Sonora, iniciadas en 1591 por los padres Gonzalo de Tapia (1561-1594) y Martín Pérez (15601626). ${ }^{124}$ Curiosamente, el padre Vidal nunca hizo referencia a las áridas regiones de la frontera del "gran Norte”. Para el polémico procurador, el referente martirial de la Compañía de Jesús no fue el septentrión novohispano, donde los jesuitas luchaban denodadamente contra el demonio fundando y manteniendo nuevas misiones, sino las lejanas islas del Pacífico. ${ }^{125}$

El 3 de marzo de 1672 el padre Vidal escribió una carta al provincial quejándose del proceder del hermano Duarte, a quien acusaba de beneficiar los intereses de las Filipinas en detrimento de la misión de las Marianas. ${ }^{126}$ Así, escribía que

Tiene tanto afecto el hermano Duarte a su Provincial de Filipinas que a los ocho Padres que vinieron este año de Europa para pasar a aquellas islas, les persuadía con notable instancia que ninguno se quedase en las islas Marianas, sino que pasasen todos a Filipinas, porque el padre Sanvitores no los había ya menester, y que bastaban seis, o siete, que había allá para aquellas islas, cuando es notoria la copiosa mies, y grande fruto, que se va cogiendo, y que necesita de muchos, y fervorosos operarios; y así ruego al V.R. mire esta causa

124 Hernández Palomo, “Acción misionera y espacio en México”, p. 104; OsANTE, “El septentrión novohispano”, pp. 69-70.

${ }^{125}$ Como señala Bernabéu, el padre Andrés Pérez de Ribas (1576-1655) en su Historia de los triunfos de Nuestra Sancta Fe entre gentes las más bárbaras y fieras del Nuevo Orbe (Madrid, 1645), como los tepehuanes, "convirtió el gran Norte en un inmenso escenario de los sufrimientos y martirios de los jesuitas, cuyas vidas heroicas demostraban que la Compañía no sólo se dedicaba a trabajar en las ricas ciudades del centro". Bernabéu, "La invención del Gran Norte ignaciano", p. 5.

126 En 1652 el hermano Duarte, nacido en Oporto, Portugal, entró en la Compañía de Jesús en la ciudad de Manila a los 28 años de edad. Según el padre Vidal Figueroa, siempre profesó un amor incondicional a las Filipinas, a donde finalmente regresó en 1689. Zambrano, Diccionario bio-bibliográfico, vol. vi, pp. 368-369). 
con piedad, y que se advierta, que el hermano Manuel Duarte con muy santo celo de su Provincia puede impedir, y embarazar, el grande fruto que aquellas islas prometen para gloria del Señor. ${ }^{127}$

Según las palabras del procurador jesuita, entendemos que "las cosas tocantes a las islas Marianas” no eran atendidas debidamente por el hermano Duarte. Sin embargo, lo que parece evidente es que el procurador general no estaba de acuerdo con destinar tantos recursos a aquellas finis terrae, especialmente cuando dichos recursos podían apoyar otras misiones novohispanas, especialmente aquellos áridos desiertos situados en la península de la Baja California Sur. ${ }^{128}$ Ante esta falta de entusiasmo de sus cofrades novohispanos, el cuerpo ilustre de la Congregación de San Francisco Javier, y especialmente el padre Vidal, actuó como principal avalador del padre San Vitores. ${ }^{129}$ Los contactos del padre jesuita en la corte española, y especialmente, los apoyos directos obtenidos de la reina gobernadora, le otorgaban poderes especiales para impulsar su proyecto misional. Según el padre Vidal, no había discusión al respecto puesto que, además, contó siempre con el apoyo incondicional del padre San Vitores. ${ }^{130}$

\footnotetext{
127 ARSI, Philipp. 13, f. 80r.

128 Unos demonios cuyas imágenes empezarán a tomar forma a principios del siglo xviti. Bernabéu Albert, “California, o el poder de las imágenes”, pp. 168-169.

129 Fray Payo de Rivera, arzobispo y virrey de México (1673-1680), biografía y testimonio. Expediente completo con la vida, muerte y obra del P. Diego Luis de Sanvitores, jesuita misionero de las Filipinas. Testimonio del padre Joseph Vidal Figueroa, procurador de las Marianas, presenta auto de virtudes. México, 13 de mayo de 1679 (Biblioteca del INAH, fondo Jesuita, rollo 1, c. 11, carp. 11, f. $18 \mathrm{r}$ ).

130 Del procurador Vidal de Figueroa decía San Vitores: “le juzgo por muy importante para las diligencias necesarias de nuestra misión en México, a las cuales atiende ya con notable celo y buenos efectos”. ARSI, México 17, f. 346r.
} 
Sin embargo, el provincial Duarte tenía serias dudas de la legalidad de los procedimientos. Según las fuentes, el padre Vidal lo acusaba no solo a él sino al provincial Pedro de Valencia de priorizar las islas Filipinas y de no querer dar ni "una cuartilla siquiera para la misión de las islas Marianas", así como de querer cobrar "10.000 pesos de los albaceas del Sr. Gobernador don Diego Salcedo, y los ponga a renta para la provincia de Filipinas, según el mismo hermano me lo ha dicho a mí". 131

A pesar de ello, el hermano Duarte se justificaba diciendo que, estando en Acapulco, ayudó al padre San Vitores y a sus compañeros "en lo que pudo", pagándoles los alimentos y prestándole "muy gruesas cantidades de pesos con que compró todo lo que llevó de México". Y añadía, de manera elocuente y con una clara intencionalidad acusatoria, que "el gasto que han hecho estos cuatro padres es tan grande como parece de las cuentas de los padres Procuradores de Madrid y Sevilla”. ${ }^{132}$ Una cuestión que debió levantar ampollas entre sus cofrades mexicanos, los cuales estaban al mismo tiempo penetrando en las regiones norteñas de la Pimería Alta de Sonora y Sinaloa. ${ }^{133}$

\section{EPÍLOGO}

Los primeros misioneros enviados al archipiélago de las Marianas no fueron simples agentes del imperialismo español, sino que estaban imbuidos de un lenguaje providencialista y metafísico que justificaba el martirio en aras de un "fin superior". La muerte de los padres Luis de Medina (Saipan, 1670), primero, y luego de su fundador, Diego Luis de San Vitores (Tumón, isla de

131 ARSI, Philipp. 13, ff. 79v.-80r. Años después, don Diego de Salcedo dejó 10000 pesos de su testamento (1668) para apoyar las misiones de las Islas Marianas. AGN, Real Hacienda, Archivo Histórico de Hacienda, vol. 326, ff. 1683r.-1696v.

132 AGN, Jesuitas I, c. 18, leg. 1-11, exp. 58, f. 205v.

133 Biblioteca del INAH, fondo Jesuita, carp. IX, rollo 2, ff. 1r.-4v. 
Guam, 1672), ${ }^{134}$ consolidó la imaginería alegórico-religiosa de la Compañía de Jesús en relación con el martirio. ${ }^{135}$ No fueron los únicos. Otros padres jesuitas, como Sebastián de Monroy (1676), Agustín Strobach, Carlos Boranga y Manuel de Solórzano (1684), junto con sus auxiliares, murieron a manos de la violencia chamorra. ${ }^{136} \mathrm{El}$ mismo Francisco Javier, su referente y modelo espiritual, no dudó en alabar a quienes sacrificaban sus propias vidas en el martirio, si fuera necesario. Así, escribía: “juzgo ser mejor morir, por favorecer a nuestra ley y fe, viendo tantas ofensas, cuantas veo se hacen, sin acudir a ellas". 137

Concebida metafóricamente como un árbol, la Compañía de Jesús extendía sus ramas desde Roma hacia cada rincón del mundo conocido donde los jesuitas habían fundado asistencias, provincias y viceprovincias. ${ }^{138}$ Manila, constituida en la capital de la provincia jesuita de las Filipinas en 1605, se ramificaba hacia las Visayas, Mindanao, Joló y otras islas circundantes del Pacífico. ${ }^{139}$ En un extremo de aquella frondosidad misional se situaban las Islas Marianas, adonde los jesuitas llegaron como parte de un proyecto universalista cristiano que se identificaba orgulloso frente a la herejía protestante.

En 1662, los jesuitas de Manila se sintieron frustrados tras el cierre del presidio de Zamboanga. El repliegue de los misioneros del sur de Filipinas fue contemplado como una injerencia de uno

134 ARSI, Philipp. 4, f. 62r.; VIDAL DE FIgUEROA, Relación de la dichosa muerte del Venerable Padre Diego Luis de Sanvitores, 1674.

135 La necesidad devocional de la monarquía católica se justificó por medio de un repertorio hagiográfico, y sobre todo iconográfico, que glorificó la conquista hispánica del archipiélago mariano y la fundación de un "estado misionero” posterior. Ciaramitaro, “Política y religión”, pp. 195-225.

136 Coello, Jesuits at the Margins, pp. 21-136.

137 BARó, “La primera mundialización”, p. 133.

138 Esta imagen del “árbol ignaciano” está representado en Horoscopium Catholicum, un grabado de Athanasius Kircher (1601-1680), Ars magna lucis et umbrae, Roma, 1646, ff. 552-553.

139 De la Costa, The Jesuits in the Philippines, p. 221. 
de los "dos cuchillos", el civil sobre el eclesiástico, lo que llevó a la Compañía de Jesús a movilizar a sus procuradores en las cortes de Madrid y Roma. ${ }^{140}$ En este contexto, la misión de las Islas Marianas, a juicio de San Vitores, parecía una salida digna del espíritu misionero de Francisco Javier, al tiempo que acallaba las críticas de sus más acérrimos enemigos. Sin embargo, no todos los jesuitas estuvieron de acuerdo en apoyar las misiones fronterizas en Asia-Pacífico. La pugna entre el hermano procurador Manuel Duarte y el padre Joseph Vidal, de la Congregación de San Francisco Javier, tiene múltiples aristas. Por un lado, ilustra las tensiones y conflictos que existieron entre los jesuitas novohispanos por la financiación de las misiones; por el otro, cuestiona el gobierno de la Compañía de Jesús como un sistema piramidal y monolítico, sin fisuras. ${ }^{141}$

Con la expedición de la Real Cédula de 1664, y sobre todo, a partir de la de 1674, se produjo, según Aspurz, una paulatina liberalización de la presencia de la Compañía de Jesús en el norte novohispano, lo que favoreció la admisión de un mayor número de extranjeros pertenecientes a las Asistencias de Germania e Italia. ${ }^{142}$ Los intereses de los jesuitas pasaban por

140 Esta teoría de las “dos espadas o cuchillos" -esto es, el temporal y el espiritual- fue formulada por vez primera por el papa Gelasio I (492-496 d. C.) en su obra De duabus in Christo naturis (Sobre la naturaleza dual de Cristo). En Gobierno eclesiástico y pacífico y unión de los dos cuchillos, pontificio y regio, el obispo agustino fray Gaspar de Villarroel nos recuerda que según la bula Unam Sanctam, promulgada por Bonifacio VIII en 1302, los dos cuchillos, que los discípulos decían que tenían para defender a Jesús de los que iban a prenderlo al huerto de los olivos (Lc. 22, 38), se interpretan como símbolo del doble poder del papa. Sólo a él le correspondía ceder el poder temporal al rey, quién a su vez, se comprometía a utilizarlo al servicio de la Iglesia. ViLLARroel, Gobierno eclesiástico y pacífico, 1656.

${ }^{141}$ Fechner, "Las tierras incógnitas de la administración jesuita”, p. 41; FECHNER, "Quando os di el orden, no os quité la prudencia”, pp. 23-56.

${ }_{142}$ La Real Cédula de 1674 permitía que fuesen extranjeros la tercera parte de cada una de las expediciones enviadas a Indias. Aspurz, La aportación extranjera a las misiones españolas, pp. 234-235. 
evaluar la abundancia y el tipo de recursos naturales que justificasen la conversión de los gentiles y posterior colonización de la península de la Baja California Sur. ${ }^{143}$ Como ya señaló Guy Rozat, los áridos desiertos del septentrión novohispano eran la morada donde los jesuitas, como los eremitas y los santos padres, esperaban derrotar al demonio. En 1672 llegaron 24 nuevos religiosos jesuitas a la Nueva España. ${ }^{144}$ Un año después, el provincial interino de los jesuitas de la Nueva España, Manuel de Arteaga (1673), SJ, envió a dos padres a las misiones de la Sierra Tarahumara (actual Chihuahua) "porque aquella nación pedía ministros que les predicasen la fe de Jesucristo". ${ }^{145}$

Aunque los jesuitas no se establecieron definitivamente sino hasta 1697, hubo diligencias previas realizadas por autoridades civiles y eclesiásticas con el fin de determinar los recursos naturales de la región tarahumara. ${ }^{146}$ Los informes recabados entre 1675 y 1677 sobre la abundancia de riquezas en California, en especial de yacimientos auríferos y argentíferos, así como de perlas y tierras fértiles, auspiciaron una expedición oficial hacia la península californiana encabezada por el almirante Isidoro de

143 Cariño y Castorena, “Las misiones jesuíticas de Baja California Sur”, pp. 131-142.

144 Aspurz, La aportación extranjera a las misiones españolas, p. 230.

145 Biblioteca del INAH, fondo Jesuita, carp. IX, rollo 2, f. 4v. Se trataba de los padres Fernando de Barrionuevo (1628- ¿? ) y Juan Manuel de Gamboa (16441721), SJ. Alegre, Historia de la Compañía de Jesús, vol. III, p. 316.

146 “Testimonio de las diligencias hechas por el capitán Nicolás Caro, protector de los indios de la nación Tarahumara en virtud del mandamiento del gobernador de la Nueva Vizcaya [Lope de Sierra y Osorio, 1643-1702] para efecto de saber las familias de indios que piden padres misioneros de la Sagrada Religión de la Compañía de Jesús para la educación y enseñanza de la religión católica y recibir el bautismo y ley evangélica, 1676-1677”. AGN, Jesuitas I, c. 18, leg. 1-11, exp. 5, ff. 52r.-57v.; "Descripción de las misiones de Sinaloa y Sonora, de sus pueblos y rancherías, número de cristianos que las habitan y gentilidad que las rodea y que están pidiendo el Santo Evangelio”, con fecha en México, 28 de febrero de 1675. ARSI, México 17, ff. 338-43r. Véase también Alegre, Historia de la Compañía de Jesús, vol. III, pp. 314-324. 
Atondo y Antillón (1639-1691) y el padre Eusebio Chini Lucci (o Francisco Kino) (1645-1711). ${ }^{147}$ Al igual que la reina Mariana protegió (y financió) el proyecto misional del padre San Vitores, doña María Guadalupe de Lencastre, VI Duquesa de Aveiro y Arcos (1630-1715) y María Luisa Manique de Lara y Gonzaga (1649-1729), esposa del virrey don Tomás de la Cerda y Aragón, Conde de Paredes (1680-1686), se convirtieron en las "madres de las misiones" del jesuita del Trentino. ${ }^{148}$ Las 23 cartas que intercambió con la Duquesa de Aveiro - desde su estancia en Cádiz, el 18 de agosto de 1680, hasta su entrada en la Alta Pimería, el 15 de febrero de $1687-$ lo atestiguan. ${ }^{149}$

Entre 1683 y 1685, las expediciones terrestres y marítimas confirmaron una imagen mítica y deformada que no obstante llevó a los misioneros jesuitas, liderados por el padre Kino, a establecerse en las regiones del Gran Nayar, Sinaloa, Ostimuri, Pimería, Tarahumara, y en la cada vez más clara península, que no isla, de California, para combatir el demonismo hasta su expulsión (1767-1768). ${ }^{150}$

Los recursos eran escasos, y por esta razón la corona vio con buenos ojos el proyecto evangelizador de los jesuitas en el septentrión novohispano. En este contexto, no resulta extraño que las autoridades ignacianas de la Nueva España se resistieran a financiar unas misiones tan ajenas al mundo novohispano como las Islas Marianas, las cuales fueron contempladas como una carga onerosa.

${ }_{147}$ Los reales de minas descubiertos en 1683 en el norte de Sinaloa consolidaron los centros mineros, como los de Promontorios, Nuestra Señora de Balvanera de La Aduana, y Minas Nuevas, en la región de los Álamos, dando lugar a la construcción de poblados junto a ricos yacimientos de plata. Cramausel, "Poblar en tierras de muchos indios", p. 18.

148 Boxer, “'The Mother of the Missions'”, pp. 733-739.

149 Burrus, Kino escribe a la Duquesa, pp. 309-313, 317-326.

150 Burrus y Zubillaga, El noroeste de México. Véase también Gerhard, The North Frontier of New Spain, pp. 264-283. 


\section{SIGLAS Y REFERENCIAS}

AHCJC Arxiu Històric de la Companyia de Jesús a Catalunya, Barcelona, España.

AGN Archivo General de la Nación, Ciudad de México, México.

AGI Archivo General de Indias, Sevilla, España.

AHN Archivo Histórico Nacional, Madrid, España.

ARSI Archivum Romanum Societatis Iesu, Roma, Italia.

BHR Biblioteca del Hospital Real, Granada, España.

BPR Biblioteca del Palacio Real, Madrid, España.

INAH Biblioteca Nacional de Antropología e Historia, "Dr. Eusebio Dávalos Hurtado”, Ciudad de México, México.

Albala, Ken y Trudy Eden (eds.), Food and Faith in Christian Culture, Nueva York, Columbia University Press, 2011.

Alegre, Francisco Javier, SJ, Historia de la Compañia de Jesús de la provincia de la Nueva España, t. III (1640-1675), Roma, IHSI, 1959.

Alegre, Francisco Javier, SJ, Historia de la Compañia de Jesús de la provincia de la Nueva España, t. IV (1676-1766), Roma, Institutum Historicum S.J., 1960.

Álvarez de Toledo y Peralta-Ramos, Cayetana, Juan de Palafox. Obispo y virrey, Madrid, Marcial Pons, 2011.

Álvarez-Osorio Alvariño, Antonio, “‘Quieren los españoles definir!” La Inmaculada Concepción y la Monarquía de España durante el siglo XvII”, en GONZÁlez ToRnel, 2017, pp. 55-73.

ARNAL, Luis, "El presidio. Instrumento de población en el septentrión novohispano”, en Bernabéu Albert, 2010, pp. 107-128.

Aspurz, Lázaro de, La aportación extranjera a las misiones españolas del Patronato Regio, Madrid, José Porrúa Turanzas, 1964.

Astrain, Antonio, SJ, Historia de la Compañia de Jesús en la Asistencia de España, t. VI (Nickel, Oliva, Noyelle, González, 1652-1705), Madrid, Razón y Fe, 1920.

Atienza de Frutos, David, “La evangelización de las 'pobres' islas Marianas y su uso simbólico en Occidente”, en Parrilla (ed.), 2012, pp. 191-216. 
Atienza de Frutos, David, “A Mariana Islands History Story: The Influence of the Spanish Black Legend in Mariana Islands Historiography", en Pacific Asia Inquiry, 4: 1 (2013), pp. 13-29.

Bailyn, Bernard y Patricia L. Denault (eds.), Soundings in Atlantic History. Latent Structures and Intellectual Currents, 1500-1830, Londres, Harvard University Press, 2009.

Baró i Queralt, Xavier, "Redescubriendo a Diego Luis de San Vitores (1627-1672): su actitud ante los nativos de Las Marianas y su obra sobre San Francisco Javier (1661)”, en Revista Española del Pacífico, 23 (2010), pp. 13-29.

Baró i Queralt, Xavier, "La primera mundialización y la mirada sobre el otro: las misiones jesuíticas en ultramar”, en PAlos y SÁnchez-Costa (eds.), 2013, pp. 129-151.

Barret, Ward, "Preface", en Mission in the Marianas. An Account of Father Diego Luis de SanVitores and His Companions (1669-1670), Minneapolis, Minnesota University Press, 1975.

Bernabéu Albert, Salvador, "California, o el poder de las imágenes en el discurso y las misiones jesuitas", en Contrastes. Revista de Historia Moderna, 12 (2001-2003), pp. 159-185.

Bernabéu Albert, Salvador, "La invención del Gran Norte ignaciano: la historiografía sobre la Compañía de Jesús entre dos centenarios (1992-2006)”, en Bernabéu Albert (coord.), 2009, pp. 165-211.

Bernabéu Albert, Salvador, El Gran Norte Mexicano. Indios, misioneros y pobladores entre el mito y la historia, Madrid, Consejo Superior de Investigaciones Científicas, 2009.

Bernabéu Albert, Salvador, Poblar la inmensidad: sociedades, conflictividad y representación en los márgenes del Imperio Hispánico (siglos XV-XIX), Madrid, Ediciones Rubeo, 2010.

Blanco, John, "Idolatry and Apostasy in the 1633 Jesuit Annual Letter", en LeE y PADrón (eds.), pp. 115-130.

Boxer, Charles, “'The Mother of the Missions", en History Today, 23: 10 (1973), pp. 733-739. 
Broggio, Paolo, "La questione dell'identità missionaria nei gesuiti spagnoli del xvir secolo", en Mélanges de l'école Française de Rome. Italie et Méditerranée, 115: 1 (2003), pp. 227-261.

Broggio, Paolo, "L'acto de contrición entre Europe et Nouveaux Mondes. Diego Luis de Sanvitores et la circulation des stratégies d'évangélisation de la Compagnie de Jesús au Xvir esiècle”, en Fabre y Vincent (eds.), 2007, pp. 229-259.

Burrieza SÁnchez, Javier, "Las Glorias del segundo siglo (1622-1700)”, en EgIDo (coord.), 2004, pp. 151-171.

Burrieza Sánchez, Javier, "Los misioneros en la Monarquía”, en Egido (coord.), 2004, pp. 189-193.

BuRrieza SÁnCHez, Javier, Jesuitas en Indias: entre la utopia y el conflicto. Trabajos y misiones de la Compañia de Jesús en la América moderna, Valladolid, Universidad de Valladolid, 2007.

Burrieza SÁnchez, Javier, "Juan de Palafox, historia de su 'fama de santidad'”, en Biblioteca: Estudio e Investigación, 27 (2012), pp. 80-108.

Burrus, Ernest J., Kino escribe a la Duquesa. Correspondencia del Padre Eusebio Francisco Kino con la Duquesa de Aveiro y otros documentos, Madrid, Ediciones José Porrúa Turanzas, 1964.

Burrus, Ernest J. y Félix Zubillaga (eds.), El noroeste de México. Documentos sobre las misiones jesuiticas (1600-1769), México, Universidad Nacional Autónoma de México, 1986.

Busquets Alemany, Anna, "Koxinga, los españoles de Manila y el alzamiento de los chinos de 1662: el testimonio de Victorio Riccio", en Revista Iberoamericana de Estudios de Asia-Oriental, 6 (2013), pp. 22-31.

CABrero, Leoncio (coord.), Historia General de las Filipinas, Madrid, Ediciones de Cultura Hispánica, Agencia Española de Cooperación Internacional, 2000.

Cariño, Micheline y Lorella Castorena, "Las misiones jesuíticas de Baja California Sur (1697-1768): cambio cultural/ambiental”, en Sorroche Cuerva (ed.), 2011, pp. 113-162.

Carrocera, Buenaventura de, OFM, "Ideas misionológicas de San Francisco Javier”, en Missionalia Hispánica, Ix: 27 (1952), pp. 644-654. 
Cervera, José Antonio y Ricardo Martínez Esquivel, "Puebla de los Ángeles, entre China y Europa. Palafox en las controversias de los ritos chinos", en Historia Mexicana, LXvIII: 1 (269) (jul.-sep. 2018), pp. 245-284.

Ciaramitaro, Fernando, "Política y religión: martirio jesuita y simbolización monárquica de las Marianas", en Convergencia. Revista de Ciencias Sociales, 78 (2018), pp. 195-225.

Coello de la Rosa, Alexandre, “El Fénix en las Marianas (1747)”, en Revista de Indias, Lxx: 250 (2011), pp. 779-808.

Coello de la Rosa, Alexandre, "Pasquines, libelos y corrupción en las Filipinas: los conflictos jurisdiccionales entre el arzobispo de Manila, fray Felipe Pardo y la Compañía de Jesús, 1677-1689", en Colonial Latin American Historical Review, 1: 2 (2013), pp. 113-145.

Coello de la Rosa, Alexandre, Jesuits at the Margins. Missions and Missionaries in the Marianas (1668-1769), Londres y Nueva York, Routledge, 2016.

Coello de la Rosa, Alexandre, “'No es esta tierra para tibios: la implicación de los jesuitas en la conquista y evangelización de Mindanao y Joló (siglo XvII)", en História Unisinos, 23: 1 (2019), pp. 47-61.

Coello de la Rosa, Alexandre, “Against Muhammad's perfidy: Francisco Combés, SJ, and his Relación de las islas Filipinas (ca. 1654)", en Journal of Jesuit Studies [en prensa, 2020].

Combés, Francisco, SJ. Historia de Mindanao, Joló y sus adyacentes. Progressos de la religion, y armas católicas, edición de Wenceslao E. Retana, Madrid, Imprenta de M. Minuesa de los Ríos [1667], 1897.

Coomans, Peter, SJ, History of the Mission in the Marianas: 1667-1673. Traducido y editado por Rodrigue Lévesque, Saipan, Occasional Historical Papers Series no 4, Divison of Historic Preservation [1673], 1997.

Cope, R. Douglas, The Limits of Racial Domination. Plebeian Society in Colonial Mexico City, 1660-1720, Madison, WI, Wisconsin University Press, 1994.

Cramausel, Chantal, "Poblar en tierras de muchos indios. La región de Álamos en los siglos XviI y xvIII”, en Región y Sociedad, 53 (2012), pp. 11-53.

De La Costa, Horacio, SJ, The Jesuits in the Philippines: 1581-1768, Cambridge, MA, Harvard University Press, 1961. 
Descalzo Yuste, Eduardo, “La Compañía de Jesús en Filipinas (1581-1768): realidad y representación", tesis de doctorado, Bellaterra, Universitat Autònoma de Barcelona, 2015.

DIAZ, Vicente M., Repositioning the Missionary: Rewriting the Histories of Colonialism, Native Catholicism, and Indigeneity in Guam, Hawái, Hawaii University Press, 2010.

Díaz-Trechuelo, Lourdes, Filipinas. La gran desconocida (1565-1898), Pamplona, Ediciones Universidad de Navarra, 2001.

EgIDo, Teófanes (coord.), Los jesuitas en España y en el mundo hispánico, Madrid, Fundación Carolina, Marcial Pons, 2004.

Elizalde Pérez-Grueso, María Dolores (ed.), Las relaciones entre España y Filipinas, siglos XVI-XX, Madrid y Barcelona, Consejo Superior de Investigaciones Científicas, Casa Asia, 2002.

Elliot, John H., España, Europa y el mundo de ultramar, Madrid, Taurus, 2009.

Fabre, Pierre-Antoine y Bernard VIncEnt (eds.), Missions religieuses modernes. "Notre lieu est le monde", Roma, École Française de Rome, 2007.

Farrell, Don A., History of the Northern Mariana Islands, Guam, Public School System of the Northern Mariana Islands, 1991.

FeCHNER, Fabián, "Las tierras incógnitas de la administración jesuita: toma de decisiones, gremios consultivos y evolución de normas", en Histórica, XXXviII: 2 (2014), pp. 11-42.

Fechner, Fabián, “'Quando os di el orden, no os quité la prudencia'. La obediencia aplicada en la administración local y en la tratadística. El caso de los jesuitas del Paraguay", en Historia y Grafía, 49 (2017), pp. 23-56.

Fechner, Fabián, "Entre el pragmatismo local y una homogeneidad global. Las normas para los jesuitas en Perú”, en Sílex, 8: 2 (2018), pp. 73-88.

Fernández Albaladejo, Pablo, La crisis de la Monarquía, vol. 4, en Fontana y Villares (dirs.), 2009, vol. 4.

Fontana, Josep y Ramón Villares (dirs.), Historia de España, Madrid, Crítica, Marcial Pons, 2009. 
GARCía, Francisco, SJ, Vida y martyrio del venerable padre Diego de Sanvitores, de la Compañia de Jesús, primer apóstol de las islas Marianas, y sucesos de estas islas... Madrid, Imprenta de Iván García Infanzón, 1683.

García-Abásolo, Antonio F., "La primera exploración del Pacífico y el asentamiento español en Filipinas”, en Elizalde (eds.), 2002, pp. 21-36.

Gerhard, Peter, The North Frontier of New Spain, Princeton, Princeton University Press, 1982.

Gil SANJuán, Joaquín, "La sinceridad de fray Alonso de Santo Tomás, obispo de Málaga, cuestionada por Antoine Arnauld”, en Baetica. Estudios de Arte, Geografía e Historia, 28 (2006), pp. 413-431.

González Tornel, Pablo (eds.), Intacta María. Politica y religiosidad en la España barroca/Unblemished Mary. Politics and Religiosity in Baroque Spain, Valencia, Generalitat Valenciana, Museu de Belles Artes de València, 2017.

Hernández Palomo, José Jesús, “Acción misionera y espacio en México: un proyecto de división provincial”, en Hernández Palomo y Moreno Jeria, 2005, pp. 87-115.

Hernández Palomo, José Jesús y Rodrigo Moreno Jeria, La misión y los jesuitas en la América española, 1566-1767: cambios y permanencias, Sevilla, Consejo Superior de Investigaciones Científicas, Escuela de Estudios Hispano-Americanos, 2005.

Hezel, Francis X., SJ, "From Conversion to Conquest: The Early Spanish Mission in the Marianas", en The Journal of Pacific History, 17: 3 (1982), pp. 115-137.

KIrcher, Athanasius, Ars magna lucis et vmbrae in decem libros digesta: quibus admirandae lucis et vmbrae in mundo, atque adeo vninersa natura, vires effectusq. vti noua, ita varia nonorum ..., Roma, Colegio Imperial, 1645 [ejemplar de la Universidad Complutense de Madrid, Biblioteca Histórica, Fondo Antiguo, BH FLL 21191].

Kosso, Cynthia y Anne ScotT, Poverty and Prosperity in the Middle Ages and Renaisssance, Turnhout, Brepols, 2012.

Ledesma, Andrés de, SJ, "Noticias de los progresos de nuestra santa fe en las islas Marianas, llamadas antes, de los Ladrones; y del fruto que han hecho en ellas, el P. Diego Luis de Sanvitores y sus compañeros, de la Compañía de 
Jesús, desde el 15 de Mayo de 1669 hasta el 28 de abril de 1670. Sacada de las Cartas, que Ha Escrito el Padre Diego Luis de Sanvitores, y Sus Compañeros" (1670) [Biblioteca del Hospital Real, Caja IMP-2-070 (31), Col. Montenegro].

Lee, Christina H. y Ricardo Padrón, The Spanish Pacific, 1521-1815. A Reader of Primary Sources, Amsterdam, Amsterdam University Press, 2020.

LÉvesque, Rodrigue, History of the Micronesia. A Collection of Source Documents, Québec, Lévesque Publications, 1995, vol. 6.

Lozano Navarro, Julián J., La Compañia de Jesús y el poder en la España de los Austrias, Madrid, Cátedra, 2005.

MacCormack, Sabine, "Conciencia y práctica social: pobreza y vagancia en España y el temprano Perú colonial”, en Revista Andina, 35 (2002), pp. 69-99.

Maggs Bros, Bibliotheca Americana et Philippina, Part III. Catálogo n 442, Londres, Maggs Bros.

Majul, Cesar Adib, Muslims in the Philippines, Diliman, Quezon City, Philippines University Press [1973], 1999.

Martínez-Serna, J. Gabriel, "Procurators and the Making of the Jesuits" Atlantic Network”, en Bailyn y Denault (eds.), 2009, pp. 181-209.

Montes González, Francisco, "Reflexiones sobre las misiones jesuíticas en el noroeste novohispano”, en Sorroche Cuerva (ed.), 2011, pp. 201-225.

Morales, Luis de y Charles Le Gobien, SJ, Historia de las islas Marianas, edición de Alexandre Coello de la Rosa, Madrid, Polifemo, 2013.

Moreno, Doris, "Obediencias negociadas y desobediencias silenciadas en la Compañía de Jesús en España, ss. XvI-XvII”, en Hispania, LXXIv: 248 (2014), pp. 661-686.

Morga, Antonio de, Sucesos de las Islas Filipinas. Edición crítica y comentada y estudio preliminar de Patricio Hidalgo Nuchera, Madrid, Polifemo, 1997.

Murillo Velarde, Pedro, SJ, Historia de la Provincia de Filipinas de la Compañia de Jesús. Segunda Parte que comprehende los progresos de esta provincia desde el año de 1616 hasta el 1716, Manila, Imprenta de Nicolás de la Cruz Bagay, 1749. 
OÑa, Diego de, SJ, Labor Evangélica. Ministerios apostólicos de los obreros de la Compañia de Jesús. Progresos de las islas Filipinas. Segunda Parte (ARSI, Philipp. 19-I, fol. 1271 ${ }^{\mathrm{r}}$.

Osante, Patricia, "El septentrión novohispano: una secular colonización hispana”, en BernabÉu Albert, 2010, pp. 43-105.

Palos, Joan-Lluís y Fernando Sánchez-Costa (eds.), A vueltas con el pasado. Historia, memoria y vida, Barcelona, Publicaciones de la Universitat de Barcelona, 2013.

Parrilla, Desiderio (ed.), La violencia del amor, Madrid, Asociación Bendita María, 2012.

Payo Hernanz, René Jesús, “Aportaciones para el estudio de la iconografía del martirio en la época contrarreformista: la imagen del padre Diego Luis de San Vitores”, en Boletín de la Institución Fernán González, 250 (2015), pp. 51-98.

PeÑa Filıu, Verónica, "Alimentación y colonialismo en las islas Marianas (Pacífico occidental). Introducciones, adaptaciones y transformaciones alimentarias durante la misión jesuita (1668-1769)", tesis de doctorado, Departament d'Humanitats, Universitat Pompeu Fabra, 2019.

Peralta De Calderón, Matías (o Diego Luis de San Vitores, SJ), El Apóstol de las Indias y nuevas gentes, San Francisco Javier de la Compañia de Jesús. Epitome de sus apostólicos hechos, virtudes, enseñanzas y prodigios antiguos y nuevos, México, Imprenta de Agustín de Santistevan y Francisco Lupercio, 1661.

Pérez SAmper, María Ángeles, "Infantas y reinas: rostros femeninos de la monarquía. Presentación”, en Pedralbes, 36 (2016), pp. 9-16.

Prieto Lucena, Ana María, Filipinas durante el gobierno de Manrique de Lara (1653-1663), Sevilla, Consejo Superior de Investigaciones Científicas, 1984.

ReICHeRT, Rafal, "La transcripción del manuscrito de fray Ignacio Muñoz sobre el proyecto de manutención y extensión de la fe católica en las Islas Marianas, y del descubrimiento y la conquista de las Islas Salomón, siglo xviI", en Estudios de Historia Novohispana, 51 (2014), pp. 133-166.

Retana, Wenceslao E., "Notas" a la edición de Antonio de Morga, Sucesos de las islas Filipinas, en MorgA, 1997. 
Risco, Alberto, The Apostle of the Marianas: The Life, Labors, and Martyrdom of Ven. Diego Luis de San Vitores, 1627-1672, Guam, Diócesis de Agaña, 1970.

Rodríguez-Rodríguez, Ana María "Francisco de Combés’s History of Mindanao and Joló (1667)”, en Lee y PAdrón (eds.), pp. 141-156.

Rogers, Robert F., Destiny's Landfall: A History of Guam, Revised Edition, Hawái, Hawaii University Press [1995], 2011.

Rubiés, Joan-Pau, "Prólogo: Apologética y etnografía en la Historia de las Islas Marianas de Luis de Morales/Charles Le Gobien", en Morales y Le Gobien, 2013, pp. 9-11.

Saborido Cursach, José Luis, ... Hasta los confines de la Tierra: Diego Luis de San Vitores, SJ, Santander, Sal Terrae, 1985.

Salvá, Jaime, "Misioneros jesuitas a Filipinas", en Missionalia Hispanica, 5 (1948), pp. 505-541.

Schumacher, John N. SJ, “Early Filipino Jesuits: 1593-1930”, en Philippine Studies, 29 (1981), pp. 271-308.

Sorroche Cuerva, Miguel Ángel, El patrimonio cultural en las misiones de Baja California, Granada, Atrio, 2011.

Strasser, Ulrike, Missionary Men in the Early Modern World. German Jesuits and Pacific Journeys, Amsterdam, Amsterdam University Press, 2020.

Vidal de Figueroa, Joseph, SJ, Carta escrita en la ciudad de México por el padre Joseph Vidal, de la Compañia de Jesús, Procurador de las Islas Marianas, a D. Gerónimo Sanvitores de la Portilla y Relación de la dichosa muerte del Venerable Padre Diego Luis de Sanvitores, Caballero del Orden de Santiago, del Consejo de su Majestad en el Real de Hacienda, México, 1674.

Villarroel, Fray Gaspar de, Gobierno eclesiástico y pacífico y unión de los dos cuchillos, pontificio y regio, Madrid, Domingo García Morrás, 1656, 2 vols.

Zambrano, Francisco, SJ, Diccionario bio-bibliográfico de la Compañía de Jesús en México, vol. v (1965), vol. vi (1966), vol. vIII (1968), vol. xII (1974), vol. xIII (1974), México, Jus. 